Policy Research Working Paper 2039

Reforming Institutions for Service Delivery

\section{A Framework for Development Assistance with an Application to the Health, Nutrition, and Population Portfolio}

Navin Girishankar
This is an argument for greater "institutional pluralism" in how the World Bank does business in the infrastructure, rural, and social sectors. Rather than monopolistic public sector provision, delivery should be governed by broad checks and balances - choice, voice, and hierarchy - that derive from the economic characteristics of the good and the institutional characteristics of the country.

The World Bank

Operations Evaluation Department

and

Poverty Reduction and Economic Management Network and

Human Development Network

January 1999 
Policy Research Working Paper 2039

\section{Summary findings}

World Development Report 1997: The State in a Changing World argued that institutions - the rules of the game that govern production and exchange - shape a country's prospects for sustained market-led growth. Girishankar provides an institutional framework for service delivery, an essential component of state capability. He applies this framework to an evaluation of Bank support for service delivery in the health, nutrition, and population sector.

He argues for greater institutional pluralism in the ways the World Bank does business in infrastructure, rural, and social sectors, but cautions against making efficient service delivery an issue of "state versus market."

The Bank and its clients face the challenge of fitting menus of "better practice" delivery options to maps of institutional reality. In the health, nutrition, and population sector, the Bank should (1) unbundle and categorize essential health and clinical services according to goods characteristics and (2) integrate country knowledge into operations through upstream assessments of state, political, and social institutions.

Overall, the Bank has made progress toward a "goods characteristics" approach, particularly in infrastructure and some rural services - but it has lagged in the social sectors, where support remains largely technocratic.
Cross-sector comparisons reveal four generations of support for service delivery.

- First-generation support focused mainly on physical implementation of projects.

- Second-generation interventions, which characterized most social service interventions, focused on improving the financial and organizational viability of implementing agencies through technical assistance.

- Third-generation support was marked by significant unbundling of service delivery activities and clearer links to goods characteristics. In irrigation (1982-94), telecommunications (1980s-present), and transport (1990s), the one-size-fits-all monopoly model gave way to a range of options based on greater private sector and citizen participation in delivery. These included leases, concessions, outsourcing, contracting, build, operate, and transfer, and turnover schemes.

- Fourth-generation interventions are works-inprogress and represent efforts to develop new governance arrangements that systematically combine competition, voice, and hierarchy in the design, delivery, and monitoring of Bank projects.

The Bank has a poor track record building country knowledge of institutional endowments that affect service delivery. Girishankar identifies concepts and tools valuable for sector specialists' operations.

This paper - a joint product of the Operations Evaluation Department, Poverty Reduction and Economic Management Network, and Human Development Network - is part of a larger effort in the Bank to develop a strategy for the reform of public sector institutions. Copies of the paper are available free from the World Bank, $1818 \mathrm{H}$ Street NW, Washington, DC 20433. Please contact Betty Casely-Hayford, room G6-078, telephone 202-473-4672, fax 202-, Internet address bcaselyhayford@worldbank.org. The author may be contacted at ngirishankar@worldbank.org.January 1999. (32 pages)

The Policy Research Working Paper Series disseminates the findings of work in progress to encourage the exchange of ideas about development issues. An objective of the series is to get the findings out quickly, even if the presentations are less than fully polished. The papers carry the names of the authors and should be cited accordingly. The findings, interpretations, and conciusions expressed in this paper are entirely those of the authors. They do not necessarily represent the view of the World Bank, its Executive Directors, or the countries they represent. 
Reforming Institutions for Service Delivery:

A Framework for Development Assistance with an Application to the HNP Portfolio

by Navin Girishankar, OEDCR 


\section{Abbreviations and Acronyms}

$\begin{array}{ll}\text { AFR } & \text { African Region } \\ \text { CAS } & \text { Country Assistance Strategy } \\ \text { EDI } & \text { Economic Development Institute } \\ \text { GOI } & \text { Government of India } \\ \text { HDNHE } & \text { Nutrition, Health, Population Team } \\ \text { HNP } & \text { Health, Nutrition, and Population } \\ \text { IA } & \text { Institutional Assessment } \\ \text { ICR } & \text { Implementation Completion Report } \\ \text { ID } & \text { Institutional Development } \\ \text { IEA } & \text { Institutional Environmental Assessment } \\ \text { IEC } & \text { Information, education and communication } \\ \text { M\&E } & \text { Monitoring and Evaluation } \\ \text { MNSED } & \text { Social and Economic Development Group \& Social Development Group } \\ \text { NGO } & \text { Non-Governmental Organizations } \\ \text { OECD } & \text { Organization for Economic Co-operation and Development } \\ \text { OED } & \text { Operations Evaluation Department } \\ \text { OEDST } & \text { Sector and Thematic Evaluation Division } \\ \text { P-A } & \text { Principal-agent } \\ \text { PMU } & \text { Project Management Unit } \\ \text { PRA } & \text { Political Readiness Analysis } \\ \text { PREM } & \text { Poverty Reduction and Economic Management } \\ \text { PRMPS } & \text { Public Sector Management Division } \\ \text { PSM } & \text { Public Sector Management } \\ \text { PSP } & \text { Private Sector Participation } \\ \text { PSR } & \text { Public Sector Reform } \\ \text { QAG } & \text { Quality Assurance Group } \\ \text { SA } & \text { Social Assessment } \\ \text { SAL } & \text { Structural Adjustment Loan } \\ \text { SD } & \text { Service Delivery } \\ \text { SDI } & \text { Service Delivery Institution } \\ \text { SECAL } & \text { Sectoral Adjustment Loan } \\ \text { SIL } & \text { Specific Investment Loan } \\ \text { SIM } & \text { Sector Investment and Maintenance Loan } \\ \text { STD } & \text { Sexually Transmitted Diseases } \\ \text { TA } & \text { Technical Assistance } \\ \text { TAL } & \text { Technical Assistance Loan } \\ \text { WDR } & \text { World Development Report } \\ \text { WHO } & \text { World Health Organization } \\ & \end{array}$




\section{Contents}

\section{Acknowledgments}

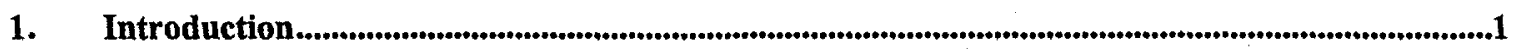

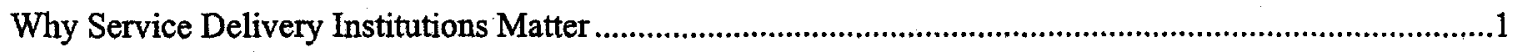

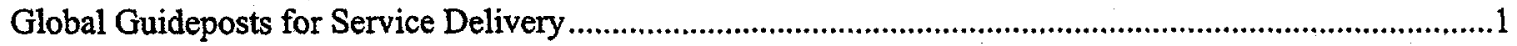

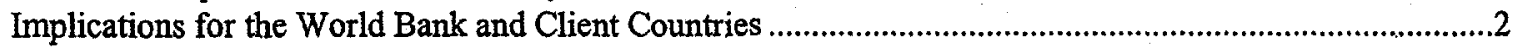

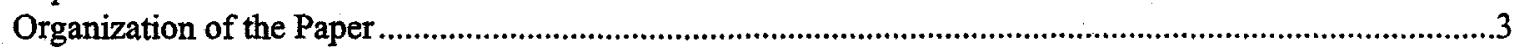

2. An Institutional Framework for Service Delivery ....................................................................................3

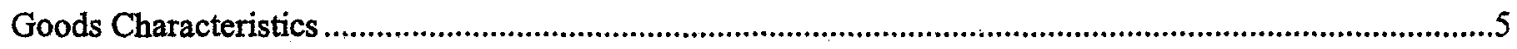

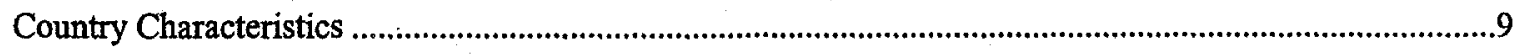

Applying the Framework ...............................................................................................................

3. Bank Support for Service Delivery in HNP ……........................................................................12

Strategy \& Implementation Record for Service Delivery Support, 1970-1997 ……..................................12

Population and Nutrition: Public Monopoly Provision, 1970-1980 .....................................................12

Direct Lending for Health: Enhancing Efficiency in the Public Sector, 1981-1989 .............................13

Clinical and Public Health: Searching for Diverse and Competitive Providers, 1990-Present ...............14

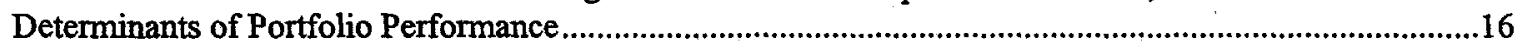

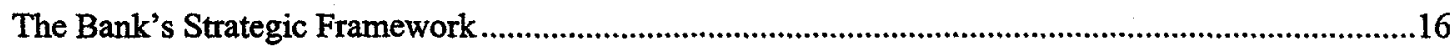

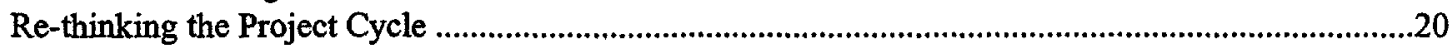

The Need for Appropriate Instruments and Processes ........................................................................22

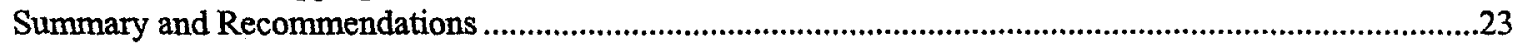

4. Evolution in Service Delivery: Challenges and Next Steps..............................................................25

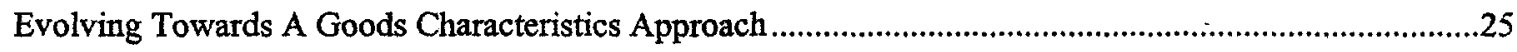

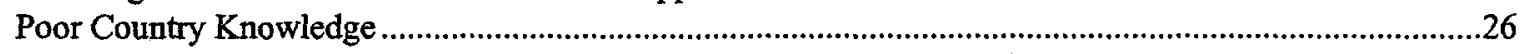

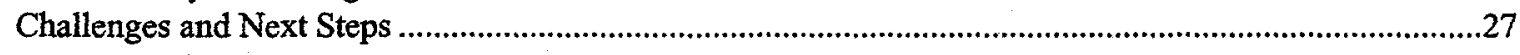

\section{Annexes}

I. Four Generations of Bank Support for Service Delivery Across Select Sectors .................................28

Bibliography

\section{Boxes}

1. Elements of a Country's Institutional Endowment Affecting Service Delivery ................................9

2. Packages of Essential Public and Clinical Health Services .............................................................15

3. Understanding Client Behavior: Social Assessment in the India Tuberculosis Control Project.........22

\section{Charts}

1. HNP Projects and Commitments by Lending Instrument, 1970-1997 ............................................13

2. OED ID Impact Ratings for HNP Projects by Approval Years, 1970-1997 .....................................16 


\section{Tables}

1. Two Stylized Paradigms of Development Assistance for Service Delivery ..........................................

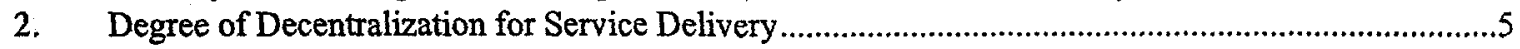

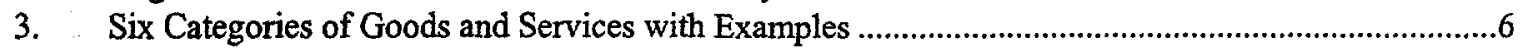

4. Mapping Institutional Options at Different Stages of a Bank Project..............................................7

5. Institutional Arrangements for Different Categories of Goods and Services ........................................

6. Characteristics of Bank Support for Health, Nutrition, and Population ..........................................12

7. Categorizing the Essential Clinical and Public Health Services by Goods Characteristics ................17

8. Corresponding Institutional Arrangements for Different HNP Services ..........................................18

9. Mapping Institutional Options for Design, Delivery, and Monitoring of HNP Services....................21

\section{Figures}

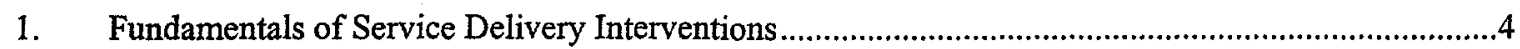

2. Assessing Elements of Country Institutional Endowment......................................................... 


\section{Acknowledgments}

The paper is the product of a collaboration between OED, PRMPS, and HDHNE. The author wishes to specially thank Brian Levy for his guidance in conceptualizing and refining the paper. Many of the ideas presented in the paper grew out of discussions with him. In addition, April Harding (PSD), Alex Preker (HDNHE), and Susan Stout (OEDST) were generous with their insights on health systems in developing and transition countries. Stout's review of the HNP portfolio was the primary source for the case study in section 3. Jennie Litvack (PRMPS), Alison Evans (OEDST), and Helcio Tokeshi also provided comments on the framework presented in the paper. Several others in OED lent their expertise including Velislava Grudkova, Timothy Johnston, Ronald Parker, Keith Pitman, Laura Raney, Binyam Reja, Tauno Skytta, Antti Talvitie, and Warren Van Wicklin. Ruben Lamdany and René Vandendries helped make the OED-PREM collaboration possible. 


\section{Introduction}

1.1 With the publication of the World Development Report 1997: The State in a Changing World, the Bank gave voice to a growing body of research on the institutional determinants of economic performance. It argued that institutions -- the rules of the game that govern production and exchange -- significantly shape a country's prospects for sustained market-led growth. Moreover, in any economy, the state plays a major role in establishing these rules. It also enjoys monopoly power over the legitimate use of coercion to enforce them. ${ }^{1}$ As a result, the institutional capability of the state has taken on greater significance with far-reaching implications for development policy and public sector reform (PSR).

1.2 This paper provides an institutional framework for service delivery (SD) -- an essential component of institutional capability. By way of example, it applies this framework to evaluate Bank support for SD in the Health, Nutrition, and Population (HNP) sector. In so doing, the paper argues for a greater degree of "institutional pluralism" in the ways the Bank does business in infrastructure as well as the rural and social sectors. By the same token, it cautions against conflating the question of efficient service delivery to one of "state versus market."

\section{Why Service Delivery Institutions Matter}

1.3 The reform of service delivery institutions (SDIs) is central to any country assistance strategy (CAS) that aims to enhance the state's ability to "secure the economic and social fundamentals" of sustained growth. The quality of a country's SDIs is a measure of its ability to ensure the provision of goods and services with positive externalities. The provision of these services typically creates conditions that are favorable to market-led growth (e.g., education, healthcare, infrastructure, irrigation). Furthermore, SD is a key locus for the evolution of the state's relationship to its citizenry. ${ }^{2}$ The very legitimacy of the state depends on how well SDIs meet the demands of citizens.

\section{Global Guideposts for Service Delivery}

1.4 In providing good practice advice to its clients, the Bank can hardly ignore global trends in SD innovation and reform over the past two decades. Since the late 1970 s, governments around the world, particularly in the OECD, have embarked on broad experiments including the use of market mechanisms and citizen participation in the delivery of basic services. ${ }^{3}$ Rapid economic, technological, and political change has compelled governments to depart from the public sector monopoly model of service provision.

1.5 Citizens, particularly in the United States, grew frustrated with what they perceived to be the state's inability to efficiently meet their demands or effectively address entrenched social problems. ${ }^{4}$ In response to taxpayer revolts and increased fiscal stringency, some public sector managers and policy leaders actively solicited the private sector and civil society as agents of

\footnotetext{
1 Eggertson, 1990.

2 Paul, 1998.

3 OECD, 1995.

4 Nye et al., 1997.
} 
service provision and arbiters of the public interest. At the same time, rapid technological change, and widespread pressure for political and administrative decentralization brought forth a sea change in the organization of work across the private, public, and non-profit sectors. ${ }^{5}$ "Networked organizations" provided greater opportunities to forge public-private partnerships. The proliferation of information technology further enhanced the accuracy and timeliness of performance monitoring as governments increasingly became purchasers rather than purveyors of public goods and services. ${ }^{6}$

1.6 The benefits of these SD reforms are both varied and well-documented. They afford a greater degree of customization for basic services in order to meet citizen demand. Furthermore, new institutional arrangements such as competition and voice place palpable pressures on providers to efficiently meet common content and performance standards for service provision. In comparison, the public monopoly model for SD has proven inadequate and unsustainable. Primarily, it has failed to provide the incentives necessary for public employees to meet client demands and perform efficiently. Even access to basic human services -- one of the major arguments for public provision -- has often fallen short of minimum consumption standards under many public monopoly regimes.

\section{Implications for the World Bank and Client Countries}

1.7 Much of the Bank's assistance in the past fifty years has been directly concerned with SD in infrastructure as well as the rural and social sectors. Its infrastructure portfolio has included a broad range of urban and rural services such as electric power, oil and natural gas, urban transport, rural roads, water supply and sanitation, as well as irrigation and drainage. In the social sectors, the Bank supports SDIs in HNP, education, labor market development, and social safety net development. In that sense, assistance to SDIs represents a dominant portion of overall Bank lending. During the FY1991-1997 period alone, infrastructure and urban development accounted for $26 \%$ of IDA and IBRD commitments overall. Human development, which includes key sectors such as education and health, received $17 \%$ of overall commitments during the same period.

1.8 The experience of numerous operational staff, evaluations by OED and QAG, and other internal reviews suggest that Bank support for SD has undergone important developments over the past four decades. For instance, alternative institutional arrangements such as concessions, leases, and outsourcing have increasingly been used in infrastructure projects. Yet, most experts would also acknowledge that much of the Bank's support for SD, particularly in the social sectors, is still narrowly technocratic (see Table 1). This technocratic approach emphasizes the transfer of technology and equipment to developing countries and implicitly assumes that monopolistic public agencies will efficiently transfer both resources and know-how. Alternative institutional arrangements such as civic participation, competition, and competition surrogates in the design, delivery, and monitoring of Bank projects are largely ignored. ${ }^{7}$ As a result, deadweight losses in the market for certain goods and services persist and the full potential of the Bank's development impact is not realized.

5 Marshall and Tucker, 1992.

6 Steering Committee for the Review of Commonwealth, 1997.

7 Israel, 1987. 
Table 1. Two Stylized Paradigms of Development Assistance for Service Delivery

\begin{tabular}{|l|l|}
\hline Technocratic Approach & Institutional Approach \\
\hline \hline $\begin{array}{l}\text { Focus largely on physical completion of } \\
\text { projects }\end{array}$ & $\begin{array}{l}\text { Emphasis on sustainability of reforms at the } \\
\text { sectoral level }\end{array}$ \\
$\begin{array}{l}\text { Public monopoly model regardless of the } \\
\text { nature of services }\end{array}$ & $\begin{array}{l}\text { Diverse delivery systems fitted to demand and } \\
\text { supply characteristics of services }\end{array}$ \\
Bundled services & $\begin{array}{l}\text { Unbundled services to apply appropriate } \\
\text { incentives to distinct activities }\end{array}$ \\
bxclusive reliance on hierarchical management & $\begin{array}{l}\text { Use of monetary/non-monetary and } \\
\text { interna1/external checks \& balances (voice and } \\
\text { choice) to provide incentives for performance }\end{array}$ \\
Government agency as the only interlocutor & Multiple interlocutors, multiple stakeholders \\
\hline
\end{tabular}

1.9 In contrast, an "institutional approach" to SD support would apply the knowledge of SD reforms in the OECD -- particularly, the appropriate use of exit, voice, and hierarchy options -- to developing and transition country contexts. It would shift the Bank's focus from organizations to the underlying rules or checks and balances that provide incentives for efficient delivery of services. It would also speak to "ground realities" by explicitly incorporating the role of politics and national institutional endowments in the Bank's strategy for SD intervention.

1.10 Clearly, there are major policy implications of this view of Bank support in SD sectors. Therefore, any program to reshape assistance strategies in SD sectors must be based on a systematic review of Bank support, with specific focus on the extent to which the institutional approach has been employed in infrastructure as well as rural and social services.

\section{Organization of the Paper}

1.11 In section 2, the paper first develops an institutional framework for Bank-supported SD reforms. Section 3 uses the institutional framework to review Bank support for SDIs in HNP. Section 4 concludes by applying generalizable lessons from the HNP evaluation to other sectors that have received Bank support. It also recommends "next steps" for strengthening Bank support in this key area of PSR.

\section{An Institutional Framework for Service Delivery}

2.1 Much of the academic and policy literature on SD as well as the Bank's own experience point to two core ideas. First, the institutional arrangements governing the design, delivery, and regulation of a service should be based on its inherent goods characteristics. The three key variables that comprise goods characteristics are measurability, information asymmetry, and 
contestability. ${ }^{8}$ Second, a government's ability to increase the efficiency and effectiveness of SD is a function of the "fit" between good practice institutional options (derived from goods characteristics) and country characteristics (see Figure 1). Typically, country characteristics are comprised of political, state, and social institutions (i.e., its institutional endowment), which shape inter alia political readiness to reform. ${ }^{9}$

\section{Figure 1. Fundamentals of Service Delivery Interventions}

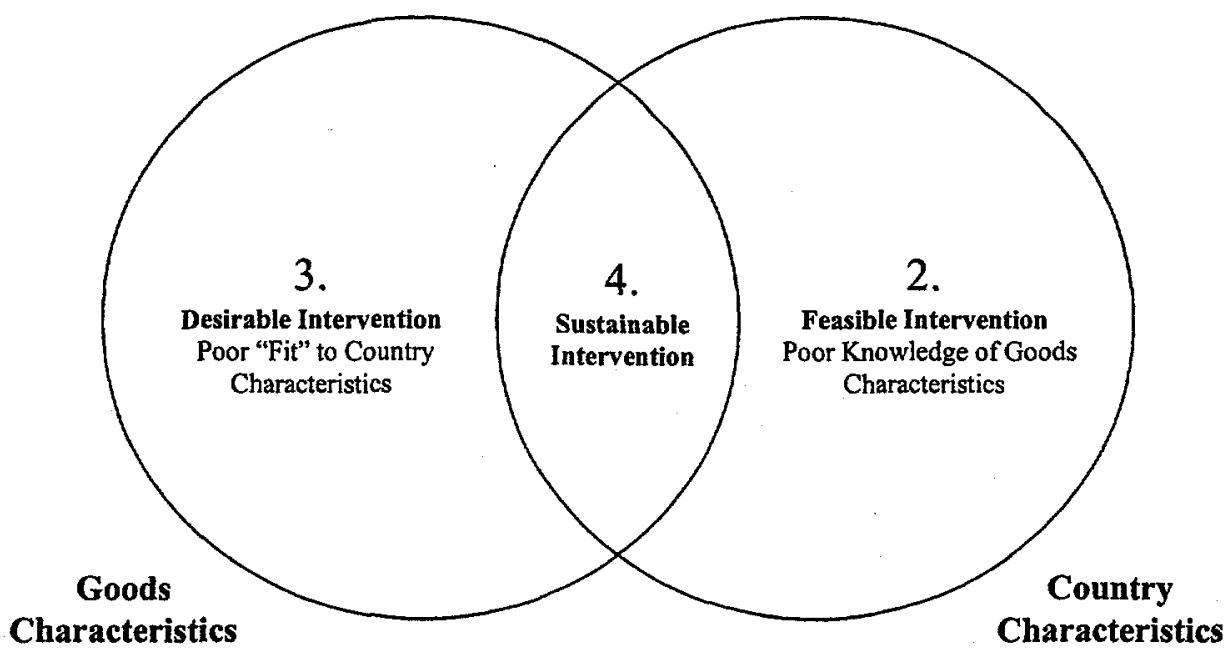

1. Poor Knowledge of Goods Characteristics Poor "Fit" to Country Characteristics

Source: Author

2.2 Achieving good fit between goods and country characteristics is an enduring challenge for Bank sector specialists and country teams. Cases where the Bank has little knowledge of either goods characteristics or country characteristics are probably very rare (Region 1 in Figure 1). On the other hand, there are cases in which borrowing governments may be knowledgeable about local conditions and are ready to implement reforms. Although such SD interventions are feasible, the Bank is unable to provide SD advice based on goods and design characteristics (Region 2). In most cases, interventions are desirable (i.e., SD reform would enhance sectoral performance) but not feasible (Region 3) because the Bank lacks knowledge of institutional characteristics that influence a country's political readiness to reform. ${ }^{10}$ Sustainable interventions (Region 4) are those that are both feasible and desirable because the Bank has successfully operationalized knowledge of both goods and country characteristics.

\footnotetext{
8 Traditionally, the public economics approach categorizes services by their consumption characteristics, namely rivalry and excludability. Of three classes of goods (public, private, mixed), public goods engender significant externalities in their provision. This form of market failure justifies collective action through public sector provision. While this approach does provide sound rationale for state intervention, it does not explain the myriad hybrid arrangements (private-public) that have emerged to enhance operational efficiency (Preker and Harding, 1998). As this paper demonstrates, categorizing by production characteristics (measurability, information asymmetry, and contestability) helps identify optimal combinations of choice, voice, and hierarchy needed for efficient provision. 9 Levy and Spiller, 1996; Haggard and McCubbins, 1997.

10 The feasibility-desirability-sustainability lexicon was adapted from the Bank's 1995 Policy Research Report, Bureaucrats in Business: The Economics and Politics of Government Ownership.
} 


\section{Goods Characteristics}

2.3 Over the past decade, a growing number of experts and practitioners has applied neoinstitutional analysis of goods or services to identify Pareto optimal institutional arrangements that govern the ownership, funding, delivery, and regulation functions of service provision (Israel, 1987; WDR 1994; Pradhan, 1996; Picciotto, 1996; WDR 1997). According to this approach, policymakers choose between combinations of participation, competition, and hierarchy after careful analysis of their respective costs and benefits in a given institutional context.

2.4 Prior to addressing delivery options, policymakers typically face questions regarding the ownership and legal status of SD agencies and funding of SD activities. Furthermore, government ownership also lends itself to the issue of the appropriate degree of decentralization. ${ }^{11}$ While both concerns are important, changing the level of government (central or local) or changing the ownership status of service delivery agencies (legally dependent, semiautonomous, or autonomous) does not necessarily affect the underlying determinants of efficiency and effectiveness. Policymakers still have to identify mechanisms for affecting the underlying checks and balances that govern SD.

2.5 Goods characteristics help identify checks and balances or institutional arrangements which provide optimal incentives for efficient design, delivery, and monitoring of services. The three economic variables that determine goods characteristics and shape delivery decisions are measurability, information asymmetry, and contestability.

* Measurability is the precision with which policymakers can specify and observe the provision of a given SD output. Accordingly, the effects of good or bad delivery performance in the provision of high measurability outputs are more easily monitored, reported and audited, even by hierarchs in the public sector. ${ }^{12}$

* Information Asymmetry is defined here as the degree to which information about SD performance is available to users or beneficiaries, but not principals within the public sector. By this definition, the information asymmetric quality of a service is at issue when the

11 Manning, 1998. Pradhan (1996) provides a way of basing decentralization decisions on the demand and supply characteristics of goods and services.

Table 2. Degree of Decentralization for Service Delivery

\begin{tabular}{|c|l|l|}
\hline Degree of Decentralization & \multicolumn{1}{|c|}{ Demand-side Factors } & \multicolumn{1}{c|}{ Supply-side Factors } \\
\hline \hline High (Local) & $\begin{array}{l}\text { Taste variation } \\
\text { Common property }\end{array}$ & $\begin{array}{l}\text { Potential for jurisdictional } \\
\text { competition }\end{array}$ \\
\hline Low (Central) & $-\begin{array}{l}\text { Spatial consumption externalities } \\
\text { Equity Concerns }\end{array}$ & $\begin{array}{l}\text { Economies of Scale } \\
\text { Cross-jurisdictional externalities }\end{array}$ \\
\hline
\end{tabular}

Source: Pradhan, 1996

Whether authority is retained, devolved, legally dependent or independent, government faces the problem of funding various SD activities. In such cases, the decision to fund producers or consumers should also be based on demand and supply characteristics. Accordingly, government funds consumers when there are either demand externalities or access/equity considerations. Governments fund providers of certain goods or services which suffer from free-rider problems in their supply such as traditional public goods.

12 Measurability is used in the same way that Israel (1987) uses specificity. 
performance of low measurability goods can be more effectively monitored by beneficiaries rather than public sector hierarchs. Therefore, information asymmetric goods benefit from voice mechanisms to adequately signal provision performance. ${ }^{13}$

* Contestability is a measure of the potential and actual competition from other suppliers for the business of the purchaser. The competitive nature of the market in which services are being purchased depends on barriers to entry and exit to producers. This includes the level of "specific capital" or the costs to other providers of entering the market for the production of that output. For low contestability goods, the high level of specific capital raises the costs to the purchaser of switching from one supplier to another. For such goods, there is also an incentive for purchaser and supplier to negotiate the terms of transactions over the life of the contract. ${ }^{14}$ Conversely, swtiching providers is easier for high contestability services, which are best provided through competitive or market pressures.

Table 3. Six Categories of Goods and Services with Examples

\begin{tabular}{|c|c|c|c|c|}
\hline Variables & \multicolumn{2}{|l|}{ High Contestability } & \multicolumn{2}{|l|}{ Low Contestability } \\
\hline $\begin{array}{l}\text { High } \\
\text { Measurability }\end{array}$ & $\begin{array}{l}\text { Type I } \\
\text { - Publishing } \\
\text { - Public transpor }\end{array}$ & & $\begin{array}{l}\text { Type II } \\
\text { - Processing tax ret } \\
\text { - Operation of ports }\end{array}$ & d railroads \\
\hline $\begin{array}{l}\text { Low } \\
\text { Measurability }\end{array}$ & $\begin{array}{l}\text { Non-info } \\
\text { Asymmetric } \\
\text { Type In-A } \\
\text { - Public legal } \\
\text { representation } \\
\text { - Policy advice }\end{array}$ & $\begin{array}{l}\text { Info Asymmetric } \\
\text { Type III-B } \\
\text { - Primary } \\
\text { education } \\
\text { - Irrigation } \\
\text { - Clinical health } \\
\text { services }\end{array}$ & $\begin{array}{l}\text { Non-info Asymmetric } \\
\text { Type IV-A } \\
\text { - Budgeting } \\
\text { - Defense } \\
\text { - Police }\end{array}$ & $\begin{array}{l}\text { Info Asymmetric } \\
\text { Type IV-B } \\
\text { - Watershed } \\
\text { management } \\
\text { projects for natural } \\
\text { conservation } \\
\text { Livestock projects } \\
\text { dependent on } \\
\text { common pastures }\end{array}$ \\
\hline
\end{tabular}

Source: Adapted from Laking, 1995; Picciotto and Grover, 1996

2.6 Using these three goods characteristics, Table 3 provides a matrix to help categorize services in six different ways along a continuum from high contestability-high measurability services (Type I) to the low contestability-low measurability-information asymmetric services (Type IV-B). Examples are also provided for each category of good or service.

2.7 Design, Delivery, Monitoring and Enforcement: Following Hirschman (1970), the WDR 1997 identified three broad sets of institutional arrangements -- exit, voice, and loyalty -- that provide incentives for efficient service provision. ${ }^{15}$ Goods characteristics indicate appropriate combinations of exit (market mechanisms), voice (participation), and hierarchy (public sector management) for different categories of services. For instance, garbage collection is a high contestability-high measurability good (Type I), which indicates that market competition would

13 There is significant empirical evidence that beneficiary participation improves the effectiveness of certain types of Bank projects (Narayan, 1995). However, researchers are still searching for an adequate economic criterion for using participation in the project cycle. See Picciotto, 1995; Pritchett, 1996.

14 WDR 1997; Hirschman, 1970; Picciotto, 1996. 
be the appropriate check and balance for its provision. As Table 4 illustrates, operational staff will have to choose between institutional options (market, participation, and hierarchy) in different stages of the Bank's project cycle, namely design, delivery, and regulation (or monitoring and enforcement).

2.8 SD interventions may use various combinations of competition, participation, and hierarchy at different stages of the project cycle. For instance, a ports project may require a hierarchical design process to define precise technical and performance requirements of the projects. Delivery of project goods, i.e., the operation of ports, could be subject to a competitive bidding arrangement, in which private firms compete for the market. The firm that provides the highest quality service at the lowest price is awarded a fixed-term contract (e.g., in the form of a lease or concession) to operate the port. Since the performance of the firm is relatively easily. monitored, the project would entrust this function to administrators within the hierarchical public sector agency awarding the lease or concession (see Type II good in Table 4).

Table 4. Mapping Institutional Options at Different Stages of a Bank Project

\begin{tabular}{|c|c|c|c|}
\hline \multirow{2}{*}{ Stage of Intervention } & \multicolumn{3}{|c|}{ Institutional Options } \\
\hline & Market & Participation & Hierarchy \\
\hline Design & & IVB & IVA \\
\hline Delivery & I & IVB & IVA \\
\hline $\begin{array}{l}\text { Monitoring \& } \\
\text { Enforcement }\end{array}$ & & IVB & IVA \\
\hline
\end{tabular}

Source: Author (based on discussions with B. Levy)

2.9 Table 4 maps out a few examples of institutional options for services across the three stages of the Bank project cycle. The easiest SD interventions are those which support the provision of high measurability-high contestability (Type I) outputs such as publishing. These goods undergo competition in the market and so design and monitoring considerations are inherent in market provision. A high measurability-low contestability (Type II) good such as the operation of ports and railroads can undergo private delivery under lease or contractual terms because only one provider can provide the service at any time. As a result, public sector principals have to define the terms of the contract and monitor the performance of the provider.

2.10 Alternatively, information asymmetric, low contestability-low measurability (Type IV-B) goods such as common pool resources require pure participation or management by selfgoverning communities during the design, provision, and monitoring stages. For instance, livestock projects dependent on common pastures are project goods or services for which neither private ownership rights (a prerequisite for competition) nor specifiable outputs (a prerequisite for effective auditing and reporting functions) exist. It is worth noting that Type IV-B services with more clearly defined property rights (e.g., irrigation with well-organized water users associations) could also undergo co-production -- a collaborative arrangement between 
beneficiaries and state actors -- in the design, delivery, and monitoring. ${ }^{16}$ Finally, noninformation asymmetric, low contestability, low measurability (Type IV-A) goods such as defense are functions which require traditional hierarchical, rules-based design, delivery, and monitoring.

2.11 As illustrated above, there are actually a great variety of institutional options available to Bank operational staff and their clients on SD projects. The adoption of these better practice options would have been Pareto improvements, which the Bank failed to secure by relying largely on public monopoly arrangements in infrastructure, social, and rural services. ${ }^{17}$ This notion has potentially far-reaching implications for the evaluation of development assistance to SD sectors as well. Bank staff in OED and QAG, who take an institutional approach to evaluation, will have to more deliberately consider whether SD interventions change the rules of the game by including new providers and new institutional arrangements (i.e., competition or voice) to enhance efficiency and effectiveness of service provision.

Table 5. Institutional Arrangements for Different Categories of Goods and Services

\begin{tabular}{|c|c|c|c|c|}
\hline Variables & \multicolumn{2}{|l|}{ High Contestability } & \multicolumn{2}{|l|}{ Low Contestability } \\
\hline $\begin{array}{l}\text { High } \\
\text { Measurability }\end{array}$ & $\begin{array}{l}\text { Type I } \\
\quad \text { Competition in the } \\
\text { Contracting }\end{array}$ & farket with Arms-length & $\begin{array}{l}\text { Type II } \\
\text { - Competition for the } \\
\text { length Contracting } \\
\text { - Audit and Report } \mathrm{C}\end{array}$ & arket with Arms- \\
\hline $\begin{array}{l}\text { Low } \\
\text { Measurability }\end{array}$ & $\begin{array}{l}\text { Non-info Asymmetric } \\
\text { Type III-A } \\
\text { Hierarchical } \\
\text { Standardization or } \\
\text { Professionalization } \\
\text { - Audit/Report } \\
\text { Inputs \& Outputs }\end{array}$ & $\begin{array}{l}\text { Info Asymmetric } \\
\text { Type III-B } \\
\text { Voice-based } \\
\text { Standardization } \\
\text { Community- } \\
\text { based planning } \\
\text { and management } \\
\text { Audit/Report } \\
\text { Inputs \& Outputs }\end{array}$ & $\begin{array}{l}\text { Non-info Asymmetric } \\
\text { Type IV-A } \\
\text { - Rules-based } \\
\text { Hierarchy } \\
\text { - Esprit de Corps }\end{array}$ & $\begin{array}{l}\text { Info Asymmetric } \\
\text { Type IV-B } \\
\text { - Co-production } \\
\text { - Stakeholder } \\
\quad \text { Feedback }\end{array}$ \\
\hline
\end{tabular}

Source: Author with adaptations from Pradhan, 1996

2.12 Table 5 generalizes the implications of mapping various institutional options by providing a comprehensive description of these options for each of the six categories of goods and services. ${ }^{18}$ These constitute a standard for SDIs given the goods characteristics of services. However, the ability of Bank operational staff and their clients to actually meet the goods characteristics standard on an infrastructure or social sector project is subject to country characteristics.

16 Ostrom, 1990.

17 Stevens, 1993.

18 Table 5 , with the inclusion of information-asymmetric goods and services, further develops specificitycontestability matrix used by the WDR 1997. 


\section{Country Characteristics}

2.13 A country's institutional characteristics determine the extent to which optimal institutional arrangements for design, delivery, and regulation can be used in Bank projects. The failure to fit goods characteristics to country characteristics may result in any number of problems on SD projects such as poor sustainability, lack of government ownership, and even inability to meet sectoral demand for services. Three sets of institutions in client countries -those governing the state, politics, and society -- are relevant to choosing country-specific SD reforms, which are also politically desirable for borrowing governments (see Box 1). Upstream assessment of political, social, and state institutions will likely enhance the relevance and effectiveness of country and sector strategies.

2.14 The Bank already uses some institutional assessment (IA) tools on sectoral operations. However, further progress is needed to adequately cover all three elements of country characteristics and standardize assessment across sectors. Currently, IA is a work in progress as described below and depicted in Figure 2.

\section{Box 1. Elements of a Country's Institutional Endowment Affecting Service Delivery \\ Political Institutions \\ - Legislative and executive institutions \\ - Character of contending social interests including the role of ideology \\ State Institutions \\ - Informal and patrimonial relationships affecting the civil service \\ - Formal accountability institutions within the core public sector (i.e., intra-public sector regulation) \\ Social Institutions (as they relate to specific SD sectors) \\ - Custom, informal, well-accepted norms that restrain individual and collective action \\ - Business, NGO, labor organizations, and civic associations \\ - Private firms}

Sources: Adapted from Levy and Spiller, 1996; Pinto, 1994

2.15 Social Institutions: Social assessments (SAs) are currently used on a variety of infrastructure, rural, and social sector projects. Increasingly, they are being applied upstream to country assistance strategies (CASs) with major implications for policy and institutional choices. $^{19}$ They are also having demonstrable influence on project design by identifying informal norms, customs, and patterns of association as well as exclusion within specific sectors. Furthermore, anecdotal evidence suggests that participatory SAs and PAs influence the willingness of task managers and country teams to use participatory methods in later phases of the project cycle. ${ }^{20}$ Ultimately, more systematic and rigorous analysis of social capital accumulation and patterns of association will enhance the value of these types of IAs. ${ }^{21}$

19 Social Inclusion and Poverty Reduction: A Technical Consultation on Albania and Armenia, 1998.

20 Social Development Family and Learning and Leadership Center, 1998. Also discussions with Janis Bernstein (MNSED) and Joanna Godinho (ECSHD) on the Uzbekistan Rural Water Supply and Sanitation Project.

21 Narayan and Pritchett, 1997. 
2.16 Political Institutions: Bank reviews of SD projects have historically cited "political will" or "lack of government commitment" as a major determinant of whether policy reforms are actually adopted. Yet, country teams have acknowledged the need for more rigorous analysis of how political institutions influence the strategy and sequencing of policy reforms, governance within a sector, and stakeholders' credible commitment to new rules for SD. ${ }^{22}$ In the last decade, advances in the study of political institutions have enabled the development of user-friendly political readiness analyses (PRAs). Haggarty and Matsuda have developed a PRA tool for task managers that draws on the political desirability, feasibility, and sustainability concepts first introduced in Bureaucrats in Business (1995). ${ }^{23}$

\section{Figure 2. Assessing Elements of Country Institutional Endowment}

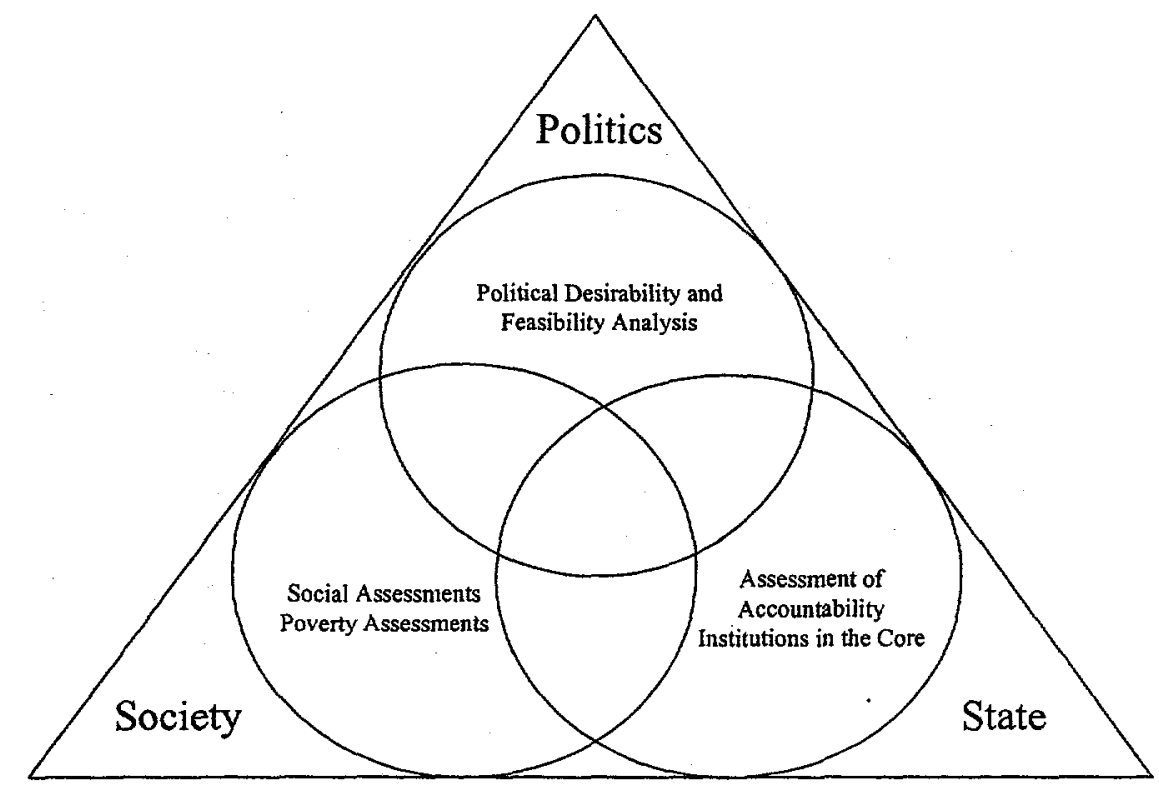

Source: Author

\subsection{Accordingly, SD reforms are characterized in three ways:}

- A reform is politically desirable, but not feasible, when a Bank intervention potentially enhances sectoral performance, yet is not aligned with either the political preferences or political incentives of key stakeholders (e.g., a sitting government, organization opposition, interest groups, etc.)

- A reform is politically feasible, but not desirable, when the political preferences of stakeholders favor reforms, yet Bank interventions fail to provide a menu of good practice SD options.

- A reform is sustainable when efficiency-enhancing interventions align with political preferences and incentives of key stakeholders. As a result, stakeholders are able to provide

22 Levy and Spiller, 1996.

23 Haggarty and Matsuda, 1998; Haggard and McCubbins, 1997. 
credible commitments to SD regimes and the government is able to overcome the formation of coalitions around reversionary policies (i.e., policies that reverse SD reforms).

2.18 After successful piloting, the Haggarty tool will enable operational staff to systematically classify SD interventions as politically desirable, feasible or sustainable. Ultimately, it will also allow the Bank to identify political institutions that hamper a borrowing government's readiness to reform.

2.19 While the Haggarty tool is particularly well-suited for analysis of systemic reforms, Berryman et al. have developed a tool that focuses on assessing institutional capability and political readiness of micro-level stakeholders during implementation. It attempts to identify relevant players, rules and incentives (in politics, administration, and civil society) that affect implementation and therefore, the likelihood of achieving desired project outcomes. ${ }^{24}$ Like the Haggarty tool, this micro-level assessment tool is ready for pilot-testing.

2.20 State Institutions: Historically, the Bank has been slow in developing tools for assessing state or core public sector institutions and their likely influence on policymaking and service delivery outcomes. A notable exception was Pinto's work (1994) on Institutional Environmental Assessments (IEAs), which attempted a governance approach to sectoral adjustment projects that relied on upstream diagnoses of formal (administrative structures) and informal (patrimonial relations) institutions affecting project design and implementation. In addition to making institutional diagnoses, the IEA was designed as a participatory assessment of the core public sector and was successfully piloted during the preparation of a Sectoral Adjustment Loan in the Gambia. ${ }^{25}$ Benefits of this IEA exercise included increased flow of information about formal and informal institutions to policymakers, broad ownership of proposed changes in the rules of the game, and greater impetus for a host of other institutional initiatives. ${ }^{26}$ This methodology was later applied to sector-specific state institutions in Zambia's education sector. ${ }^{27}$

2.21 Since the publication of WDR1997, the Bank has more systematically identified those aspects of the state's internal machinery that help restrain arbitrary action in policymaking and budgeting. Without appropriate internal checks and balances on cabinet-level actors, collective decisionmaking in the executive is not mutually binding. There is also a greater likelihood that SD sectors will suffer from arbitrariness, uncertainty, and inefficiency. PREM is in the process of preparing assessments of accountability mechanisms on executive decisionmaking within the core public sector. ${ }^{28}$

\section{Applying the Framework}

2.22 The framework outlined above helps identify combinations of checks and balances (or institutional arrangements) that enhance the efficiency of the design, delivery, and regulation of services. It also identifies the types of institutional characteristics of countries that shape policy choices. There is growing demand for IA tools that would enable the Bank to fit state-of-the-art

\footnotetext{
24 Berryman et al., 1997.

25 Pinto, 1994.

26 Ibid., p. 7.

27 Pinto, 1995.

28 Manning et al., 1998.
} 
advice to the particular characteristics of client countries. The next section uses this framework to review the Bank's support for SD in the HNP sector.

\section{Bank Support for Service Delivery in HNP}

3.1 This case study of HNP analyzes the extent to which the Bank recommended countryspecific, "better practice" institutional options for the delivery of clinical and public health services. Accordingly, section 3 describes the evolution of the Bank's involvement in HNP (including its assistance strategy, use of instruments, and outcomes). It then highlights the institutional determinants of portfolio performance and provides recommendations for improving the goodness of fit between good practice institutional options for delivery and country context. The evidence presented here is largely drawn from OED's recent portfolio review of HNP lending as well as companion sector impact evaluations.

\section{Strategy \& Implementation Record for Service Delivery Support, 1970-1997}

3.2 Since 1970, Bank support for SDIs in HNP has been defined by three more or less distinct generations. The first two generations relied largely on the public monopoly model for service provision in population and nutrition (1970-1980) and clinical health (1981-1989) respectively. From 1990, a third generation of SDI support began to emerge even as increases in direct lending to health made HNP one of the fast growing Bank portfolios. In this third generation, the Bank has attempted to shift its focus from geographically-specific projects to sectoral reforms, which solicit alternative providers of health services as key stakeholders. The evolution of these three generations -- (i) public monopoly provision of population and nutrition services, (ii) increasing the efficiency of public sector monopolies in HNP, and (iii) the search for diverse and competitive health providers -- is presented in Table 6.

Table 6. Characteristics of Bank Support for Health, Nutrition and Population, 1970-1997

\begin{tabular}{|c|c|}
\hline $\begin{array}{l}\text { Population and Nutrition, } 1970-1980 \\
\text { Direct Lending for Health, 1981-1989 }\end{array}$ & $\begin{array}{l}\text { Clinical and Public Health: Searching for } \\
\text { Diverse and Competitive Providers, 1990-Present }\end{array}$ \\
\hline $\begin{array}{l}\text { - } \text { Geographically-specific project objectives } \\
\text { - Channel technical expertise to reduce } \\
\text { constraints } \\
\text { - Public monopoly provision with investments in } \\
\text { public sector capacity building }\end{array}$ & $\begin{array}{l}\text { - Systemic or policy level project objectives } \\
\text { - Expand services and invest in the long-run } \\
\text { sustainability of the sector } \\
\text { - Financial reform primarily through user fees } \\
\text { - Introduction of NGOs as providers }\end{array}$ \\
\hline
\end{tabular}

Source: Adapted from Stout and Johnston, 1998

Population and Nutrition: Public Monopoly Provision, 1970-1980

3.3 Between 1970 and 1980, the Bank's health-related activities were primarily focused on population and nutrition; they targeted key development constraints associated with rapid population growth. With the publication of WDR 1984: Population and Development, the need for population policy was further justified in terms of reducing the gap between the private and 
social net benefits of having many children. ${ }^{29}$ At the same time, the Bank failed to provide economic rationale for the public monopoly delivery arrangements it recommended for family planning and nutrition. It implicitly assumed that public sector monopolies would satisfy the "unmet [family planning and nutrition] needs" of citizens. Accordingly, concepts such as consumer demand and service utilization were largely absent from supply-side population and nutrition interventions.

3.4 Investment lending, comprising Specific Investment Loans (SILs) and Sector Investment and Maintenance Loans (SIMs), was the instrument of choice for Bank interventions in this early period. During the 1970-1980 period, the Bank approved 22 population projects, two nutrition projects, and three health sector projects with commitments totaling \$510.9 million. According to OED, only $58 \%$ of audited projects in this young portfolio had satisfactory outcomes. The overwhelming majority of projects from this period $(77 \%)$ were not rated for either institutional development (ID) impact or sustainability. Of those that were rated, only one-third achieved substantial ID impact and two-thirds were likely to be sustainable.

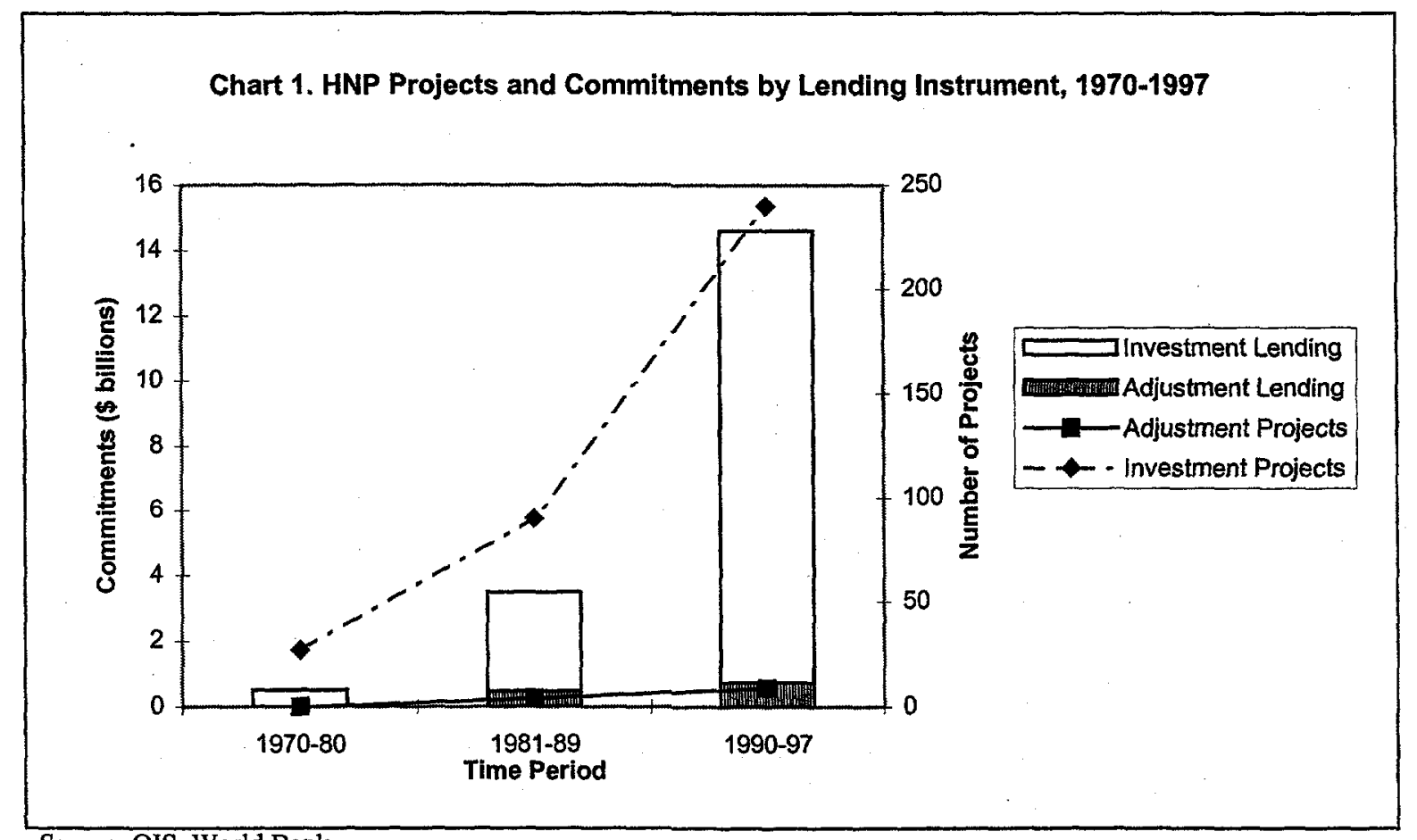

Source: OIS, World Bank

Direct Lending for Health: Enhancing Efficiency in the Public Sector, 1981-1989

3.5 In the decade following the 1978 "Health for All by the Year 2000" Conference in AlmaAta, the Bank's program of dramatically increasing direct lending for health reflected the global consensus on guaranteed access to basic health services. As its commitments to health rose between 1981 and 1989, the Bank integrated its population, health and nutrition portfolios and began to more explicitly consider the role of the state in the delivery of HNP services. Government intervention was now justified on grounds of equity and market failures in the provision and financing of health care. Allocative issues of health expenditure gained

29 Stout et al., 1997. 
prominence as policymakers recognized the demand externalities associated with basic health provision. This emphasis on increasing inputs to the health system served to obscure issues of technical efficiency. The assumption that public monopolies would efficiently provide health sector outputs remained largely unquestioned.

3.6 Between 1981 and 1989, Bank commitments to HNP grew rapidly to over $\$ 3$ billion. Investment lending continued to be the Bank's main instrument even as health sector projects grew in size and complexity, particularly in regions with weak institutions such as AFR. ${ }^{30}$ Cognizant of the tendency to design complex projects in weak institutional settings, the Bank responded with public sector capacity building initiatives on health sector projects. According to OED, over $83 \%$ of all projects in the portfolio sought to enhance the capacity of public sector agencies. Capacity building concerns included improving skills, increasing resources of agencies, improving information systems as well as budgeting and planning. In addition to capacity building, the Bank aimed to utilize decentralization as a mechanism to make health sector interventions more efficient. While its economic justification was not clearly articulated, decentralization was recommended as a SD component in nearly $40 \%$ of projects in the entire * HNP portfolio. ${ }^{31}$

3.7 Despite attempts to improve the organizational quality of public sector health providers, only $19 \%$ were judged to have substantial ID impact. Furthermore, only $60 \%$ of HNP projects rated by OED during the 1981-1989 period had satisfactory outcomes and 43\% were rated likely to be sustainable. This suggests that the public monopoly model for SD, even when supplemented by capacity building components, is not sufficient for realizing efficiency and effectiveness on Bank projects.

Clinical and Public Health: Searching for Diverse and Competitive Providers, 1990 - Present

3.8 In the World Development Report 1993: Investing in Health, the Bank began to articulate a definitive role for public policy in the HNP sector. According to the Bank, the state should ensure access to essential packages of both public and clinical health services, while encouraging a competitive and diverse mosaic of participants in health sector funding, delivery, and regulation (see Box 2). The government's role in guaranteeing the essentials of public and clinical health was justified on grounds of (i) alleviating poverty, (ii) providing pure public goods or goods with significant demand externalities, and (iii) correcting market failures in both health care and health insurance.

3.9 For the delivery of clinical services, the 1993 WDR recommended three mechanisms other than public monopolies -- greater decentralization of public healthcare provision, improved hospital management, and stronger regulation of private providers. First, decentralizing the planning and management of health services to the provincial or district level was considered a means of increasing responsiveness to local needs and improving technical efficiency.

Nevertheless, the Bank noted pitfalls such as the lack of local capacity or the inability of clients to hold local officials accountable. In other words, decentralization of health planning by itself does not provide sufficient checks and balances on the delivery of public and clinical health services. Second, managerial reforms in hospitals such as autonomization, corporatization, and outsourcing were noted as avenues for achieving significant efficiency gains. Finally, the Bank

30 Stout and Johnston, 1998.

31 Ibid. 
recognized that encouraging competition between private providers in the health sector would require increased regulatory capacity to monitor and enforce publicly and professionallymandated standards.

\section{Box 2. Packages of Essential Public and Clinical Health Services}

\section{Package of Essential Public Health Services}

- Expanded program on immunization and micro-nutrient supplementation

- School health programs to treat worm infections and micronutrient deficiencies

- Programs to increase public knowledge about family planning and nutrition, self-cure, and vector control/disease surveillance activities

- AIDS prevention program with strong STD component

\section{Package of Essential Clinical Health Services}

- Prenatal and delivery services

- Family planning

- Integrated management of the sick child (including diarrheal diseases, acute respiratory infections (ARIs), and malaria)

- Treatment of tuberculosis

- Case management of sexually-transmitted diseases (STDs)

Source: Investing in Health, WDR 1993

3.10 In the $1990 \mathrm{~s}$, concerns about technical efficiency have grown with increasing HNP commitments. In fact, between 1990 and 1997, the Bank approved 249 HNP operations with total commitments of $\$ 13$ billion. While investment lending (e.g., SIMs, SILs) remained the dominant instrument for Bank support, sectoral adjustment lending and social funds were increasingly utilized for HNP interventions (see Chart 1). To some extent, the use of adjustment lending was a function of the Bank's shift from a project-based to a systemic focus, which included "major organizational change" or "financial reform." According to OED's recent review of HNP lending, 52\% of projects approved during FY1995-97 had a systemic focus as opposed to only $33 \%$ for those approved during FY1985-89.

3.11 In some cases, sectoral reform proposals included recommendations for alternative funding and delivery arrangements such as decentralization, user fees, and partnerships with NGOs. In particular, decentralization was a component of nearly $75 \%$ of post- 1990 operations. However, it was not clear whether decentralization was actually designed to elicit either "voice" or "choice" as a SD mechanism. When recommendations were made to establish voice and private sector participation (PSP) mechanisms outside the public sector, they were mainly in the post- 1990 period. Even in the $50 \%$ of post- 1990 operations that did commit to use NGOs in delivery, virtually none assessed the capacity and character of the NGO sector during project preparation. Intensive supervision or ex post evaluation will be required to determine whether Bank projects actually employed NGOs either as competitive providers or conduits for consumer voice. Despite the 1993 WDR's strategic framework for HNP delivery, post-1990 projects rarely incorporated PSP or its variants (e.g., autonomization, corporatization) at the time of appraisal.

3.12 Of the 13 completed projects which OED has audited from the early $1990 \mathrm{~s}, 69 \%$ received satisfactory ratings for outcomes and $62 \%$ for sustainability. Despite these improvements on second generation performance, only $26 \%$ were judged to have substantial ID impact. This evidence corroborates the view that substantial progress in ID requires systematic unbundling of 
public sector monopolies through the appropriate use of voice or choice in delivery. The failure to realize changes in the rules of the game explains why ID ratings on average have not improved significantly on HNP projects since the 1981-1989 period (see Chart 2). As far as ongoing projects are concerned, $29 \%$ of all HNP projects currently under supervision are considered "at risk," which compares favorably to the Bank-wide average of $30 \%$, but poorly to other social sector averages. Management problems and inappropriate location of projects are cited as prime sources of problems for on-going operations.

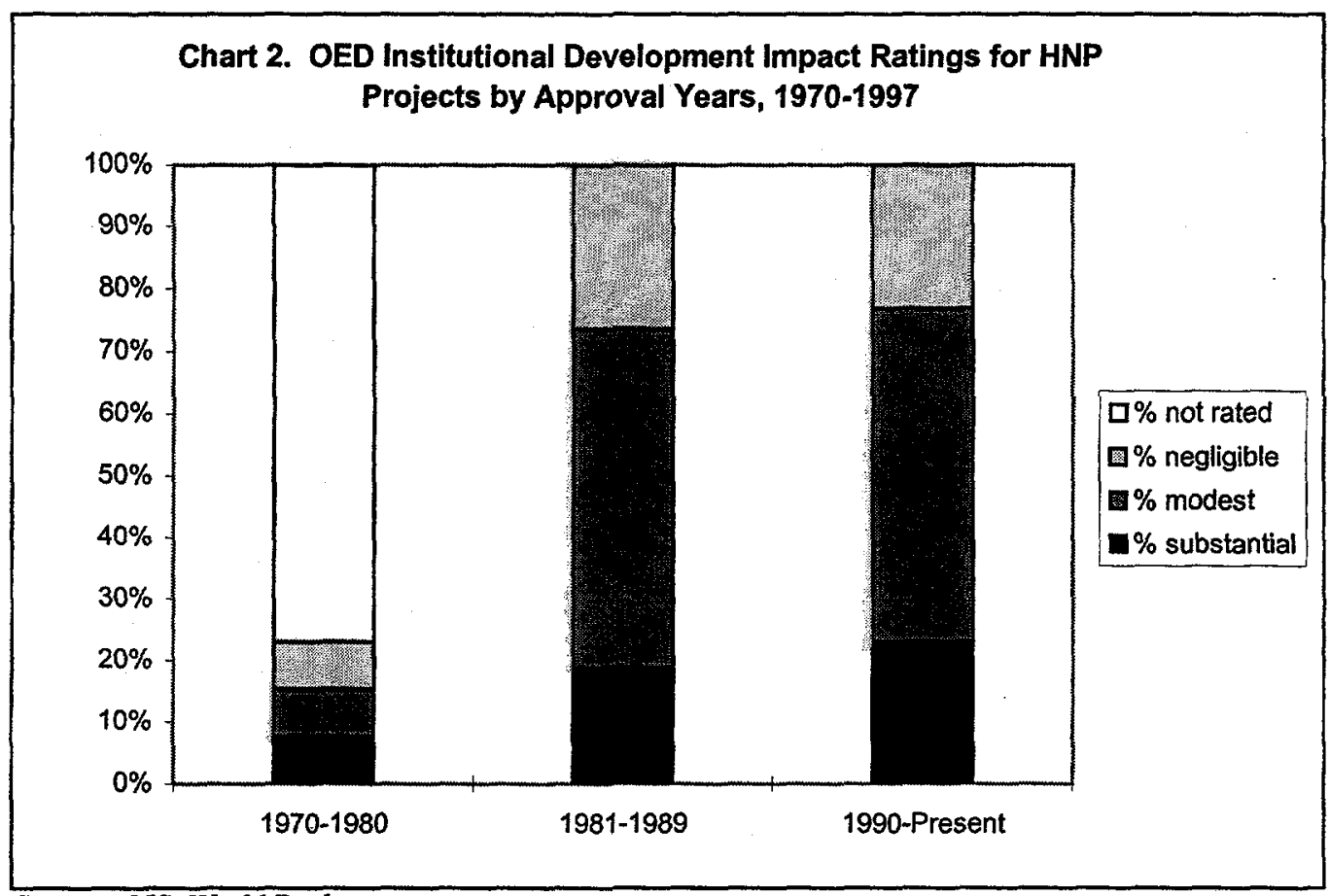

Source: OIS, World Bank

\section{Determinants of Portfolio Performance}

3.13 A number of factors have limited the effectiveness of the Bank's HNP portfolio during the 1980s and 1990s. Of these, the quality of Bank support for SDIs clearly has been a major determinant of outcome performance. In fact, when used as an evaluative tool, the goods and country characteristics framework (described in section 2) actually illustrates how Bank strategy, processes, and instruments could have been shaped quite differently in order to enhance relevance and effectiveness.

\section{The Bank's Strategic Framework}

3.14 The 1993 WDR made an important contribution to SD in HNP by clearly defining "essential packages" of clinical and public health services and justifying the role of public policy in guaranteeing access and efficient delivery of these services. At the same time, the report stopped short of deriving a menu of better practice delivery arrangements from the goods characteristics of clinical and public health services. This conceptual gap explains the Bank's tendency to rely heavily on public monopoly approaches to SD in most HNP interventions. As a result, the institutional dimensions of Bank support for HNP generally lagged behind advancements in infrastructure sectors, where PSP became a standard plank of Bank strategy by the early 1990s. 
3.15 Ignored Goods Characteristics. Over the past decade, the public monopoly approach has been the subject of growing criticism. Since the late 1980s, internal reviews of HNP lending have increasingly cited a range of problems that are endemic to monopolistic SD systems. These include inadequate focus on consumer demand, poor fit between project design and institutional capacity, and a failure to systematically incorporate PSP or voice in service provision. ${ }^{32}$ Aside from some recent recommendations to base the government's role in delivery and financing on an economic classification of health activities, most HNP reviews have not used the goods characteristics approach as an evaluative tool. ${ }^{33}$ For the purposes of this paper, Table 7 categorizes various health sector services according to neo-institutional criteria.

Table 7. Categorizing Essential Clinical and Public Health Services by Goods Characteristics

\begin{tabular}{|c|c|c|c|c|}
\hline Variables & \multicolumn{2}{|l|}{ High Contestability } & \multicolumn{2}{|l|}{ Low Contestability } \\
\hline $\begin{array}{l}\text { High } \\
\text { Measurability }\end{array}$ & $\begin{array}{l}\text { Type I } \\
\text { - Pharmaceut } \\
\text { - Medical Suf }\end{array}$ & & $\begin{array}{l}\text { Type II } \\
\text { - Expensive High }\end{array}$ & hnology Services \\
\hline $\begin{array}{l}\text { Low } \\
\text { Measurability }\end{array}$ & $\begin{array}{l}\text { Non-info } \\
\text { Asymmetric } \\
\text { Type III-A } \\
\text { - } \quad \begin{array}{l}\text { Management } \\
\text { Services }\end{array} \\
\text { - } \quad \begin{array}{l}\text { Support } \\
\text { Services }\end{array} \\
\text { - } \quad \text { Immunization } \\
\text { - } \begin{array}{l}\text { Screening of } \\
\text { donors to } \\
\text { prevent blood } \\
\text { borne } \\
\text { transmission }\end{array}\end{array}$ & $\begin{array}{l}\text { Info Asymmetric } \\
\text { Type III-B } \\
\text { Most Clinical and } \\
\text { Public Health Services } \\
\text { Family planning } \\
\text { Integrated management } \\
\text { of Sick Children } \\
\text { Programs to reduce } \\
\text { consumption of } \\
\text { tobacco, alcohol, and } \\
\text { other drugs } \\
\text { Dissemination of health } \\
\text { and scientific } \\
\text { information }\end{array}$ & $\begin{array}{l}\text { Non-info } \\
\text { Asymmetric } \\
\text { Type IV-A } \\
\text { - Epidemiological } \\
\text { Surveillance } \\
\text { - Research }\end{array}$ & $\begin{array}{l}\text { Info Asymmetric } \\
\text { Type IV-B }\end{array}$ \\
\hline
\end{tabular}

Source: Author

3.16 As indicated in Table 7, the Bank's HNP portfolio in a given country is typically comprised of a complex assortment of goods -- from epidemiological surveillance (Type IV-A) to medical supplies (Type I). This diverse basket of $\mathrm{HNP}$ goods in turn requires an equally diverse menu of delivery arrangements. Put simply, the goods characteristics approach implies that Bank projects in HNP should employ various combinations of voice, choice, and hierarchy at different stages of the project cycle (see Table 8). For instance, immunization is a low measurability, non-information asymmetric, high contestability good that avails itself to professional standardization in design and monitoring, as well as PSP in delivery. The appropriate delivery option would be to contract with multiple private, public, and non-profit providers in order to maximize access and efficiency. These providers would then be audited by central disease control authorities for inputs (e.g., the quality of vaccines) and outputs (e.g., numbers vaccinated).

32 Stout, 1997.

33 Musgrove, 1996. 
Table 8. Corresponding Institutional Arrangements for Different HNP Services

\begin{tabular}{|c|c|c|c|c|}
\hline Variables & \multicolumn{2}{|l|}{ High Contestability } & \multicolumn{2}{|l|}{ Low Contestability } \\
\hline $\begin{array}{l}\text { High } \\
\text { Measurability }\end{array}$ & \multicolumn{2}{|c|}{$\begin{array}{l}\text { Type I } \\
\text { - } \quad \begin{array}{l}\text { Private sector participation in provision of } \\
\text { pharmaceuticals supplies }\end{array}\end{array}$} & \multicolumn{2}{|c|}{$\begin{array}{l}\text { Type II } \\
\text { - Competitive bidding for expensive, } \\
\text { high technology services; with auditing } \\
\text { of outputs }\end{array}$} \\
\hline $\begin{array}{l}\text { Low } \\
\text { Measurability }\end{array}$ & $\begin{array}{l}\text { Non-info Asymmetric } \\
\text { Type III-A } \\
\text { Private participation } \\
\text { in immunization } \\
\text { and screening } \\
\text { subject to } \\
\text { professional health } \\
\text { standards } \\
\text { "One-stop } \\
\text { shopping" for case } \\
\text { management of } \\
\text { STD patients } \\
\text { Fixed-term } \\
\text { contracting for } \\
\text { management and } \\
\text { support services; } \\
\text { reporting of outputs } \\
\text { and inputs by public } \\
\text { and private } \\
\text { professionals }\end{array}$ & $\begin{array}{l}\text { Info Asymmetric } \\
\text { Type III-B } \\
\text { - } \quad \text { Beneficiary } \\
\text { participation in } \\
\text { family planning } \\
\text { - Community-based } \\
\text { primary care (with } \\
\text { both modern and } \\
\text { traditional healers) } \\
\text { "One-stop } \\
\text { shopping" for } \\
\text { integrated } \\
\text { management of } \\
\text { the sick child with } \\
\text { parental feedback } \\
\text { Providing public } \\
\text { information on } \\
\text { HNP with } \\
\text { feedback from } \\
\text { clients }\end{array}$ & $\begin{array}{l}\text { Non-info } \\
\text { Asymmetric } \\
\text { Type IV-A } \\
\text { - Hierarchical } \\
\text { management of } \\
\text { disease control } \\
\text { and surveillance } \\
\text { functions (at } \\
\text { local or national } \\
\text { levels) }\end{array}$ & $\begin{array}{l}\text { Info Asymmetric } \\
\text { Type IV-B }\end{array}$ \\
\hline
\end{tabular}

Source: Author

3.17 Similarly, prenatal and delivery care is a low measurability, high contestability, information asymmetric good. It should be provided by community or private health workers subject to professional and public standards. The information-asymmetric quality of prenatal and delivery care implies clients have information regarding the performance of providers which hierarchs in government do not. Therefore, it requires voice mechanisms both in design and monitoring to ensure responsiveness to client demand. A clear message from this exercise is that the Bank is rarely justified in not providing a menu of institutional options for delivery. Alternatively, there are very few cases in which the Bank should rely exclusively on public monopoly SD arrangements at all stages of the HNP project cycle. Yet, several reviews and audits of Bank involvement reveal that PSP and voice have not been systematically employed at either the national or local levels. Only four completed HNP projects used voice mechanisms in ways that afforded significant decision-making authority to beneficiaries.

3.18 While qualitative improvements in the use of voice and choice on HNP projects were rare, the Bank frequently recommended "decentralization" as a way of enhancing the technical efficiency of health services. It is worth noting that certain forms of decentralization do allow for the credible use of voice (by devolving planning and management) and competition (through inter-jurisdictional competition if people can "vote with their feet"). However, recommendations for decentralization in HNP were generally not linked to goods characteristics of services. Nor 
were they systematically linked to the social and political realities of client countries. This suggests that the Bank has taken a "hit or miss" approach to decentralization in HNP rather than a selective, institutional one.

3.19 The Bank's role in Brazil's health system is a case in point. An OED sectoral impact study of HNP in Brazil found that the "Bank's stance on health decentralization has never been clear and comprehensive." The failure to identify and incorporate factors in the country institutional endowment into Bank strategy has led, at times, to contradictory policies with respect to decentralization. By way of example, the report added:

"The Sao Paulo project sought to support the health decentralization underway in the middle 1980 s, but the complexity of politics in that state, as well as the Bank's failure to appreciate it in full, resulted in a project that was not well articulated with the evolving governance of the state...The recent health sector reform, Reforsus, supports decentralization by encouraging managerial development, but its emphasis on setting national cost-effectiveness priorities places its strategy in conflict with the objective of local autonomy and regional diversity in SUS (Single Health System) prices. ${ }^{, 34}$

3.20 These findings illustrate the dangers of making formulaic recommendations for decentralization without considering the challenges posed by a country's institutional endowment. It also shows how Bank support for decentralization could very easily resemble supply-driven assistance to centralized public monopolies. By focusing on building managerial capacity in local governments, rather than changing the underlying rules for delivering outputs, the Bank may inadvertently encourage municipal and provincial administrators to reproduce monopolistic arrangements and generate significant deadweight loss in local healthcare markets.

3.21 Not Fitted to Country Characteristics. According to OED, institutional analysis (including analysis of borrower ownership and client demand) had stronger influence on HNP outcomes than economic analysis. Yet, the Bank's overall failure to assess and incorporate institutional factors into its projects and sector strategies constitutes a major oversight. As is described below, assessments of state, political, and social institutions rarely informed either Bank strategy or project design. ${ }^{35}$

* State Institutions: At appraisal, virtually all HNP projects cited poor borrower capacity in implementing agencies as a project risk. Yet, OED reports that $69 \%$ of the Implementation Completion Reports (ICRs) for unsatisfactory projects argued that capacity should have been more thoroughly assessed. Furthermore, as the distinction between capacity and institutions remained vague, capacity assessments focused largely on training of personnel rather than on incentives. In fact, only $17 \%$ of projects analyzed the incentive structures of government officials and service providers and only $30 \%$ discussed incentives at all (including incentives of service providers). In addition, few projects analyzed the regulatory and legal environment governing health service provision. It is also worth noting that in spite of the Bank's willingness to recommend decentralization, less than half of the projects recommending decentralization actually assessed the intra-public sector legal environment affecting intergovernmental relations.

34 Gauri, 1998.

35 Stout and Johnston, 1998. 
* Political Institutions: OED's review noted that $30 \%$ of appraisal documents for HNP projects cited some form of political resistance from bureaucrats, providers, etc. However, only $5 \%$ (all approved since FY1990) of these appraisals included some form of interest group analysis. In addition, poor ownership by borrowers was noted in nearly $40 \%$ of all completed projects and $55 \%$ of ICRs for unsatisfactory projects. This is in part the result of the vagueness of prevailing definitions of ownership in general. Ownership is often defined in terms of verbal expressions of support for project objectives rather than institutional or structural factors that shape the incentives for key political actors to reform.

* Social Institutions: While NGO participation in implementation was as an explicit project goal in the post-1990 phase of lending, few projects analyzed the capacity of the NGO sector. Analysis of traditional institutions, particularly as they relate to women's active participation in the HNP sector, was also absent from Bank project documents as well. Finally, the size and character of the private healthcare providers, which requires regular monitoring and assessment, were rarely reported at appraisal.

3.22 The introduction of new players and delivery options necessarily opens Bank projects to a vast array of institutional factors that influence project design and implementation. In countries with more developed PSP and voice arrangements, demand for routine IAs is likely to increase for both lending and non-lending services.

\section{Re-thinking the Project Cycle}

3.23 As described above, Bank support for SD in the HNP sector has guided by a largely technocratic approach, paying scarce attention on the incentive framework for delivery or new providers. By contrast, the institutional approach would have required the Bank to engage a broader range of interlocutors in the design, delivery, and monitoring phases of the project cycle. For instance, Table 9 shows how Type III-B goods such as family planning would undergo participatory design processes as both beneficiaries and professional technocrats collaborate in better defining content and performance standards for that particular HNP service. Typically, social assessments (SAs) would help identify factors such as custom, politics, and patronage networks that influence consumer behavior. Then, borrowing governments could rely on private providers of contraceptives, health information, and personalized counseling to compete in the delivery of family planning services. When appropriate, the Bank could solicit traditional healers' assistance in strengthening communities' willingness to use and demand modern family planning services, Subsequently, the monitoring of SD could be conducted jointly by professional health sector technocrats (using traditional analytical techniques) and consumers (through surveys and participatory mechanisms in which experts take a facilitating role vis-à-vis beneficiaries). ${ }^{36}$

36 Narayan, 1993. 
Table 9. Mapping Institutional Options for Design, Delivery, and Monitoring of HNP Services

\begin{tabular}{|c|c|c|c|}
\hline Stage of Intervention & Market & Participation & Hierarchy \\
\hline Design & & IIIB & IIIB \\
\hline Delivery & IIIB & & \\
\hline $\begin{array}{l}\text { Monitoring \& } \\
\text { Enforcement }\end{array}$ & & IIIB & $\rightarrow$ IIIB \\
\hline
\end{tabular}

Source: Author

3.24 In reality, even those HNP projects that aspire to an institutional approach generally lack adequate processes and instruments to incorporate new players and new institutional arrangements. Without new Bank processes and instruments, it is unrealistic to expect significant substantive improvements in support for HNP. Overly ambitious HNP projects in poor institutional environments can easily generate a downward spiral of poor outcomes. In fact, OED's review found that the HNP portfolio was caught in a vicious cycle of designing overly complex projects in countries to compensate for low institutional quality and poor existing health conditions (e.g., low rate of decline of infant mortality). Breaking this vicious cycle is ultimately a matter of (i) injecting a greater degree of realism into project preparation and (ii) using instruments and processes that are appropriate for systemic objectives.

3.25 First, the argument for realistic expectations is in fact an argument for institutional assessment. Without basic information about consumer preferences or NGO sector capacity, the Bank will not be able to define or implement sectoral strategies. Nor will it be able to fit "better practice" delivery options for goods to specific country needs. In fact, OED found a "disturbing lack of attention to consumer dernand" as well as a failure to monitor service utilization rates on HNP interventions. As can be expected, $69 \% \mathrm{HNP}$ projects through FY1986 did not have clientresponsive services. ${ }^{37}$ SAs as well as other IA tools would help remedy these problems during project identification and preparation (see Box 3).

37 Stout and Johnston, 1998. 
Box 3. Understanding Client Behavior: Social Assessment in the India Tuberculosis Control Project

Background. India faces a tuberculosis crisis with more than 1.2 million cases reported every year and an annual mortality rate of nearly 500,000. The Government of India (GOI), with the help of the Bank and WHO, revised its TB control program to encourage directly observed treatment, i.e., when patients take prescribed drugs in the presence of health workers or trained personnel. It also focused on infectious patients to curb transmission.

The Social Assessments (SAs). A major obstacle in the battle against TB is the failure of patients to complete their treatment. Project planners knew that overcoming this obstacle required knowledge of factors influencing both the behavior of TB patients and their relationship to service providers.

Accordingly, SAs of urban slum dwellers and tribals were designed as part of the project's Information, Education, and Communication (IEC) component. The SAs aimed to (i) collect and analyze socioeconomic data, (ii) solicit the participation of urban and tribal stakeholders in planning, and (iii) develop social indicators related to project performance.

Findings. Four key SA findings contributed to the (re)design of the TB control project.

* Poverty - Most patients did not complete treatment because they were poor. They were unable to pay for transportation, medicine, treatment by private practitioners. The poor also could not sustain the income foregone while collecting their medicine. Finally, the rural poor did not have access to primary health centers. These problems were exacerbated in the case of women, whose activities were limited in comparison to those of men.

* Service Providers -- Government, NGO, and private practitioners provided TB services. Of these, patients first sought out private practitioners because they felt that the latter would treat them with greater respect than other providers. They also valued the greater privacy afforded by private practitioners. Finally, patients perceived free government medicine to be of poorer quality. Since NGOs were not major providers of TB treatment and private practitioners did not provide adequate follow-up, most patients ended up with government providers when the disease was advanced. These government providers, who administered directly observed therapy, serviced the largest number of compliant patients.

* Stigma and Secrecy -- The stigma associated with TB was a major disincentive to patients seeking or completing treatment. This stigma was higher among urban slum dwellers and was inversely correlated with their level of education. In some areas, TB stigma was so strong that even health workers kept diagnoses secret.

* Communication -- Word of mouth communication through compliant and cured patients was the most effective means of spreading information about the disease. Yet most physicians posted in tribal areas did not speak the local language or understand tribal culture. Furthermore, many patients also felt the government-sponsored providers are routinely blamed them for noncompliance.

Impact of the SA on the Project. SA findings enabled the project team to develop a more focused IEC strategy, a new approach to involving private physicians, and better ways of measuring project outcomes.

Source: Environment Department, Social Assessment Series, 1997

\section{The Need for Appropriate Instruments and Processes}

3.26 The ancillary issue of instruments and processes is central to the Bank's ability to leverage changes in the incentive framework for SD at the sectoral level. Despite a growing trend towards using sectoral adjustment lending on HNP projects, the Bank's HNP portfolio is still largely comprised of investment lending (i.e., SILs, SIMs, and TALs). However, the supplydriven, geographically-specific character of investment loans may reinforce the public monopoly 
model with the government agency as the Bank's sole interlocutor. The portfolio would benefit from adjustment lending, which affords greater leverage in achieving reforms at the sectoral or systemic level. For more localized interventions, social funds allow for greater experimentation with alternative governance structures in which government is no longer the sole purveyor of SD systems. Furthermore, these funds support demand-driven pilots that produce demonstration effects, encourage learning, and behavioral change in the HNP sector.

3.27 Successful transition in HNP requires that traditionally technocratic processes in project management, supervision, evaluation give way to more decentralized ones. Project management and supervision were primarily designed to help a single public sector agency meet the short-run physical implementation objectives of investment operations. Fifteen percent of the ICRs noted that project management units (PMUs) undermined project ownership as their enclave function prevented integration in the mainstream of the ministry in question. ${ }^{38}$ In general, PMUs were narrowly focused on "protecting" projects from poor ownership (i.e., political resistance) rather than building broad coalitions (e.g., among technocrats, legislators, beneficiaries, and providers) to meet the Bank's broader HNP objectives. Inadequate supervision was also cited as a problem in over $70 \%$ of ICRs for unsatisfactory projects. Moreover, the quality of supervision was a pressing concern particularly in monitoring institutional change on nearly one third of completed projects. In the future, the Bank and borrowers will have to develop new indicators for monitoring institutional change, sectoral performance and political readiness while increasing supervision effort. In this regard, the Bank's decision to decentralize HNP supervision to the national level demonstrates foresight.

3.28 As with other areas of Bank involvement, monitoring and evaluation (M\&E) of HNP projects suffered. Data on the performance of projects was rarely collected or analyzed. Few ICRs provided data that systematically linked national data on health status to project inputs and outputs. OED's review of HNP lending also found that performance measurement of HNP projects was significantly better on single-purpose population projects rather than general health sector reform projects. ${ }^{39}$ In so far as evaluation is itself a key development institution, the Bank should think broadly about using voice, exit, and hierarchical options to monitor performance. Since service statistic systems (in the public sector) tend to be "highly burdensome at the point of service delivery," alternative evaluation institutions should be actively employed on Bank projects -- e.g., participatory evaluation for community obstetrics (Type III-B goods) or private sector auditing of hospital management (Type III-A goods).

\section{Summary and Recommendations}

3.29 Bank support for SDIs in the HNP sector has been largely technocratic, relying on one delivery model -- the public sector monopoly -- for a great variety of clinical and health services. The public monopoly approach generally ignored the influence of institutions as well as the political realities of the health sector reform. As a result, outcomes performance, ID impact, and sustainability of the HNP portfolio have suffered.

3.30 OED's review of HNP lending verified a number of key hypotheses set forth by the framework presented in section 2 . Accordingly, substantive and process lessons identified in the case study may have remained obscure without an institutional approach.

38 Ibid.

$39 \mathrm{Ibid}$. 
Bank strategy in HNP should be guided by the following substantive recommendations:

* Systematically categorize essential health and clinical services according to goods characteristics with appropriate menus of SD arrangements. Use this goods characteristics scheme as a benchmark for country and sector strategies.

* Conduct ex ante institutional assessments (including SAs and political readiness analyses) of the private sector, the state, and the informal sector during project identification and upstream of HNP sector strategies.

* Require lending and non-lending services to provide clear economic (i.e., goods characteristic) rationale for the use of either public monopolies or recommendations for decentralization.

Corresponding changes in Bank processes and instruments should be considered as well:

* Rely more on adjustment lending to leverage changes in the incentive framework for delivery at the sectoral level.

* Use social funds for localized interventions in order to demonstrate demand-driven delivery while encouraging learning and behavioral change on a micro-level.

* Routinize IAs of state, political, and social institutions in identification and preparation.

* Utilize alternative project management strategies to build stakeholder support for project and sectoral objectives rather than narrowly achieving physical implementation targets of projects.

* Decentralize supervision functions to engage a larger number of interlocutors in both monitoring and ex post evaluation functions. 


\section{Evolution in Service Delivery: Challenges and Next Steps}

4.1 Lessons from the preceding case study of HNP resonate across sectors including infrastructure, social and rural services. In each of these sectors, the Bank faces the challenge of fitting menus of "better practice" delivery options to maps of institutional realities. As illustrated in the HNP case, this requires the Bank to (i) unbundle and categorize the bundle of project goods and (ii) integrate country knowledge into the implementation of SD arrangements.

\section{Evolving Towards A Goods Characteristics Approach}

4.2 Even a cursory glance across sectors reveals that the Bank has made important strides towards a goods characteristics approach, particularly in infrastructure. ${ }^{40}$ Yet it has lagged behind in the social sectors, where SD support remains largely technocratic. Cross-sectoral comparisons reveal that Bank support for SD has evolved into four generations. First generation support, particularly in infrastructure and rural services, was primarily focused on physical implementation of projects. The state's monopolistic role in implementation was largely assumed in sectors such as irrigation (1948-1971), telecommunications (pre-1970s), and highway construction (1970s). Heavy reliance on investment lending reinforced this bias as the public sector was the Bank's sole interlocutor. ${ }^{41}$ OED ratings of outcomes were generally satisfactory because projects met short run physical implementation targets. In hindsight, however, these "successes" often obscured low sustainability, ineffective targeting of poor beneficiaries, etc. ${ }^{42}$

4.3 While they did not question the public monopoly for service provision, second generation interventions were increasingly concerned with the financial and organizational viability of implementing agencies. Cost recovery and O\&M management became a key ID objective in irrigation (1972-1981), telecommunications (1970-1980), and urban transport (mid1970s-1980s). ${ }^{43}$ Supply-driven technical assistance was used to "substitute for local deficiencies on a temporary basis -- e.g. for project preparation - or to introduce into a functioning organization or system an incremental improvement by means of short-term advisory services or narrowly focused training." 44 Substitution TA may have helped achieve physical implementation targets, but it did not address the underlying institutional constraints on sectoral performance. Demand for services tended to outstrip supply as public monopolies proved inadequate in areas such as telecommunications, energy, and HNP. In addition, the low ID impact of projects indicated that the Bank required a systemic or sectoral focus in order to change the underlying incentive framework for SD. ${ }^{45}$

4.4 The third generation of SD support, particularly in infrastructure (late 1980s-early 1990s), proved to be a watershed for the Bank and its clients. Advancements in technology and global transportation enabled greater unbundling of SD activities that were previously

40 Section 4 drew from OED sector studies, audit reports, and Bank-wide reviews of infrastructure, rural, and social services. Annex I summarizes the evolution of Bank support for SD across sectors.

41 Barbu, 1994.

42 Stout, 1998.

43 Jones, 1992.

44 Steedman, 1995.

45 Ibid.; Barbu, 1994. 
aggregated. This unbundling of project goods was a major step towards the goods characteristics approach described in section 2 . For the first time, goods characteristics were linked to delivery arrangements in irrigation (1982-1994), telecommunications (late 1980s-present), railways (1980s), airports (1990s) and transport overall (1990s). As a result, the one-size-fits-all public monopoly model gave way to a range of options such as leases, concessions, contracting for the market, outsourcing, BOT and turnover schemes, etc.

4.5 As it recommended the break-up of public monopolies, the Bank shifted its focus from individual projects to sectoral, policy-based reforms. Adjustment proved more effective than investment lending in leveraging policy reforms that encouraged PSP and citizen participation in meeting sectoral demand. For instance, SECALs, SALs, and multisector adjustment lending played a prominent role in unbundling telecommunications services and de-monopolizing public utilities in the sector. ${ }^{46}$

4.6 In some sense the prevalence of high-measurability project goods in infrastructure allowed the Bank to move relatively quickly towards a goods characteristics approach. By the same token, the low measurability of many social goods arguably contributed to the Bank's reluctance to abandon the public monopoly model in these sectors. The full potential of the goods characteristics approach may be realized in fourth generation interventions that develop new governance arrangements, which combine competition, voice, and hierarchy in the design, delivery, and monitoring stages of projects. Some illustrative operations are the Andhra Pradesh Forestry, Uzbekistan Water Supply and Sanitation, and Albania Rural Poverty Alleviation.

\section{Poor Country Knowledge}

4.7 Overall, the Bank has a poor track record in building country knowledge of institutional endowments that affect SD. Specifically, SD support across sectors has rarely incorporated assessments and models of state, political, and social institutions into project design. One difficulty in assessing the Bank's work in building country knowledge is the absence of institutional analysis in evaluations themselves. Most evaluations have only recently begun analyzing goodness of fit between better practice and institutional context. ${ }^{47}$

4.8 At any rate, the Bank's approach to decentralization in HNP is illustrative of the dangers of overlooking country institutional factors in sector strategies. Without country knowledge, decentralization has the potential of becoming a blueprint solution to problems that were themselves created by the one-size-fits-all public monopoly model. Even when it is appropriate for a particular HNP good, public provision at the local level should be assessed in the context of institutional constraints on the ground (e.g., social relationships between local elites and the poor, central-local relations, or bureaucratic quality). Ultimately, the Bank and its clients require more than sound frameworks and workable IA tools. Country teams and sector units will need unambiguous incentives to meet established standards for good fit on SD operations.

\footnotetext{
${ }^{46}$ Barbu, 1994.

${ }^{47}$ Stout, 1998.
} 


\section{Challenges and Next Steps}

4.9 The remaining challenges for the Bank are therefore both conceptual as well as operational. The concepts and tools identified in this paper are only as valuable as sector specialists' ability to operationalize them in the project cycle. In this regard, the following next steps are proposed to mainstream the institutional approach to SD reform.

* Pilot the SD framework for assessments upstream of Country Assistance Strategies (CASs) and sector strategies in select sample countries. Use the findings and recommendations from the pilots as benchmarks for CASs or for concurrent CASs in countries with similar institutional constraints.

* Disseminate results of the pilots to sector specialists through the networks in order to further develop and refine the tools.

* Develop menus of workable institutional options for the delivery of specific services (e.g., clinical health or basic education) in each sector.

* Develop benchmarks for SD support based on these menus of institutional options and "goodness of fit" to country context. Use these benchmarks to evaluate and compare the quality of Bank SD support across client countries.

* Systematically incorporate the institutional framework presented in this paper into evaluation methodologies for Country Assistance Reviews/Notes and audits. This will provide a visible incentive for sector specialists to adopt both goods characteristics and country characteristics approaches. 


\section{Annex I. Four Generations of Bank Support for Service Delivery Across Select Sectors}

\begin{tabular}{|c|c|c|c|c|}
\hline Generations & $\begin{array}{l}\text { 1. The Assumption of } \\
\text { Public Monopoly }\end{array}$ & $\begin{array}{l}\text { 2. Making Public Monopolies } \\
\text { More Efficient }\end{array}$ & 3. Breaking Government's Monopoly & $\begin{array}{l}\text { 4. Beyond Public Maladies \& Private } \\
\text { Panaceas }\end{array}$ \\
\hline $\begin{array}{l}\text { Providing Good } \\
\text { Practice Advice } \\
\text { based on Goods } \\
\text { Characteristics }\end{array}$ & $\begin{array}{l}\text { State As Purveyor } \\
\text { - Design, Delivery, and } \\
\text { M\&E }\end{array}$ & $\begin{array}{l}\text { An Efficient Public Monopoly } \\
\text { - Design, Delivery, and M\&E } \\
\text { - Inefficiencies identified } \\
\text { - Lack of sustainability } \\
\text { - Input-driven TA } \\
\text { - Pessimistic of the ability of private or } \\
\text { beneficiary to efficiency manage } \\
\text { hardware }\end{array}$ & $\begin{array}{l}\text { Introducing New Arrangements } \\
\text { - Which players are effective? } \\
\text { - PSP alone confuses organizations and } \\
\text { institutions, content for form. } \\
\text { - Private/participatory involvement in } \\
\text { funding, design, delivery, and M\&E } \\
\text { - Funding is open to user fees, government } \\
\text { funding when their are demand } \\
\text { - externalities or min consumption standards } \\
\text { - Autonomy as best incentive for } \\
\text { management } \\
\text { - Contracting arrangements } \\
\text { - Emphasis on private-public mix rather than } \\
\text { incentives in both sectors } \\
\text { - Regulation: independent, hierarchical, but } \\
\text { with discretion } \\
\text { - Participation noted as important } \\
\text { - Shift from agency to sectoral focus }\end{array}$ & $\begin{array}{l}\text { Improving Enforcement of New Rules } \\
\text { - Which rules of the game are effective? } \\
\text { - Public not by proprietorship but by commitment } \\
\text { to publicly mandated standards } \\
\text { - Diversity of P-A arrangements that require } \\
\text { classification and nuanced evaluation } \\
\text { - The importance of M\&E as a technical good } \\
\text { practice for software and hardware } \\
\text { - Hardware and software affect each other } \\
\text { fundamentally and should be integrated in } \\
\text { operations } \\
\text { - Regulation has to be subject to checks and } \\
\text { balances as well. Incentives for regulators. } \\
\text { Organizational independence is not good } \\
\text { enough -- still need to deal with issues of voice } \\
\text { and discretion } \\
\text { - Central strategic planning capacity for service } \\
\text { delivery (a service delivery brain trust) as a } \\
\text { counterpart for the Bank } \\
\text { - Sectoral and Country Focus }\end{array}$ \\
\hline $\begin{array}{l}\text { Lending } \\
\text { Instruments }\end{array}$ & - Investment Lenđing & $\begin{array}{l}\text { - Investment Lending with Technical } \\
\text { Assistance }\end{array}$ & $\begin{array}{l}\text { - Adjustment Lending with Technical } \\
\text { Assistance }\end{array}$ & $\begin{array}{l}\text { - Adjustment Lending } \\
\text { - Social Funds }\end{array}$ \\
\hline $\begin{array}{l}\text { Examples of Bank } \\
\text { Involvement by } \\
\text { Sector and Time } \\
\text { Period }\end{array}$ & $\begin{array}{ll}\text { - Inigation (1948-71) } \\
\text { - Telecom (Pre-1970s) } \\
\text { - Highways (Until late } \\
\text { 1970s) }\end{array}$ & $\begin{array}{l}\text { - Irrigation (1972-81) } \\
\text { - Telecom (1970-80) } \\
\text { - HNP (1981-94) } \\
\text { - Highways (1ate 1970s) } \\
\text { - Urban Transport (mid-1970s-80s) }\end{array}$ & $\begin{array}{l}\text { - Irrigation (1982-94) } \\
\text { - Telecom (late 1980s- Present) } \\
\text { - HNP (1994-Present) } \\
\text { - Railways (1980s) } \\
\text { - Transport overall (1990s) } \\
\text { - Airports (1990s) }\end{array}$ & $\begin{array}{l}\text { lect on-going operations in: } \\
\text { - Water Supply \& Sanitation (Uzbekistan, } \\
\text { Paraguay) } \\
\text { - Forestry (India) } \\
\text { - Rural Poverty Alleviation (Albania) }\end{array}$ \\
\hline
\end{tabular}

Source: Author 


\section{Bibliography}

Barbu, Alain. 1994. The Bank's Experience in the Telecommunications Sector: An OED Review, OES, Washington, D.C.: World Bank.

Berryman, Sue et al. 1997. "Guidelines for Assessing Institutional Capability," Draft for Testing, Washington, D.C.: World Bank.

Dia, Mamadou. 1996. Africa's Management in the 1990s and Beyond: Reconciling Indigenous and Transplanted Institutions. Washington, D.C.: World Bank.

Eggertson, Thráinn. 1990. Economic Behavior and Institutions. New York: Cambridge University Press.

Environment Department. 1997. Social Assessment Influences Design of the India Tuberculosis Project. Dissemination Notes, Social Assessment Series, No. 54, Washington, D.C.: World Bank, May 1997.

Gauri, Varun. 1998. The Brazil Health System: A Sector Impact Study. Sector Impact Study for Review of Development Effectiveness in the HNP Sector, OEDST, Washington, D.C.: World Bank.

Haggard, Stephan and Mathew D. McCubbins. 1997. "Political Institutions and the Determinants of Public Policy: An Introduction," in Political Institutions and the Determinants of Public Policy: When Do Institutions Matter? eds. Haggard and McCubbins, San Diego, CA: University of California, June 1997.

Hirschman, Albert. 1970. Exit, Voice, and Loyalty: Responses to Decline in Firms, Organizations, and States. Cambridge, Mass.: Harvard University Press.

Israel, Arturo. 1997. A Guide for the Perplexed: Institutional Aspects of Social Programs. Social Programs and Sustainable Development Department. Washington, DC: Inter-American Development Bank. . 1987. Institutional Development. Washington, D.C.: Johns Hopkins University Press.

Jones, William. 1992. The World Bank and Irrigation. Operations Evaluation Study, Washington, D.C.: World Bank.

Johnston, Tim. 1998. The Impact of World Bank Support to the HNP Sector in Zimbabwe. Sector Impact Study for Review of Development Effectiveness in the HNP Sector, OEDST, Washington, D.C.: World Bank.

Laking, Robert. 1995. "An Approach to Public Management Reform,": Working Paper, Public Sector Management Unit, Washington, D.C.: World Bank.

Levy, Brian and Pablo Spiller, eds. 1996. Regulations, Institutions, and Commitment:

Comparative Studies in Telecommunications. New York: Cambridge University Press. 
Manning, Nick. 1998. "Unbundling the State: Autonomous Agencies and Service Delivery," Unpublished Draft, Washington, D.C.: World Bank, April 1998.

Manning, Nick et al. 1998. "Disciplined Cabinet Decisionmaking: A Pragmatic Approach to Mutually-Binding Decisions in Collective Executives," Unpublished Draft, Washington, D.C.: World Bank, August 1998.

Marshall, Ray and Marc Tucker. 1992. Thinking For A Living. New York: Harper and Collins Publishers.

Musgrove, Philip. 1996. "Public and Private Roles in Health: Theory and Financing Patterns." Working Paper. Human Development Department, Washington, D.C.: World Bank.

Narayan, Deepa. 1995. The Contribution of People's Participation: Evidence from 121 Rural Water Supply Projects. Environmentally Sustainable Development Occasional Paper Series No. 1, ESD, Washington, D.C.: World Bank.

Narayan, Deepa and Lant Pritchett. 1997. Cents and Sociability: Household Income and Social Capital in Tanzania. Social Development and Development Research Group, Poverty and Human Resources, Washington, D.C.: World Bank, July 1997.

Nye, Joseph, Philip Zelikow, and David King, eds. 1997. Why People Don't Trust Government. Cambridge, Mass.: Harvard University Press.

Organization for Economic Co-operation and Development. 1995. Governance In Transition: Public Management Reforms in OECD Countries. Paris: OECD.

Ostrom, Elinor. 1990. Governing the Commons: The Evolution of Institutions for Collective Action. New York: Cambridge University Press.

Paul, Sam. 1998. "Making Voice Work: What Happened to the Report on Bangalore?" PREM Seminar Series, Public Sector Group, Washington, D.C.: World Bank, March 4, 1998.

Picciotto, Robert and Neelima Grover. 1996. "Rural Development: Hierarchy or Participation?" Paper for Panel on Alleviating Rural Poverty: Selected Topics in Collection Action and Institutional Reform, Washington, D.C.: Sixty-Sixth Conference of the Southern Economic Association.

Picciotto, Robert and Eduardo Wiesner, eds. 1998. Evaluation and Development: The Institutional Dimension. New Brunswick, NJ: Transaction Publishers.

Pinto, Rogerio with assistance from Angelous J. Mrope. 1994. Projectizing the Governance Approach to Civil Service Reform: An Institutional Environment Assessment for Preparing a Sectoral Adjustment Loan in the Gambia. World Bank Discussion Paper 252, Washington, D.C. 1995. Assessing Sector Institutions: Lessons of Experience from Zambia's Education Sector. World Bank Discussion Paper 297, Washington, D.C. 
Pradhan, Sanjay. 1997. "Public-Private Partnerships for Service Provision," Background Paper for World Development Report 1997, Washington, D.C.: World Bank.

Pritchett, Lant. 1996. "Participation: What, Why, Who and When," Paper for New Thinking on Aid Effectiveness.

Rice, E.B. 1997. Paddy Irrigation in Southeast Asia. OES, Washington, D.C.: World Bank.

Steering Committee for the Review of Commonwealth/State Service Provision. 1997. Reforms in Government Service Provision 1997, Melbourne: Commonwealth of Australia.

Stevens, Joe B. 1993. The Economics of Collective Choice. Boulder, Colorado: Westview Press.

Social Development Family and Learning and Leadership Center. 1998. Social Assessment: Understanding How People and Society Affect and Are Affected by Development Interventions. Washington, D.C.: World Bank.

Haggarty, Luke and Yasuhiko Matsuda. 1998. "Assessing Clients' Commitment to Sectoral Reforms: A Reform Readiness Analysis," Washington, D.C.: World Bank.

Skytta, Tauno. 1992. Water Supply and Sanitation Projects: The Bank's Experience - 1967-1989. OES, Washington, D.C.: World Bank.

1994. Twenty Years of Lending for Urban Development 1972-92: An OED Review. OES, Washington, D.C.: World Bank.

Steedman, David. 1995. Governance and the Design of Technical Assistance for Institutional Development. Department Papers Series, No. 11, Asia Technical Department, Washington, D.C.: World Bank, April 1995.

Stout, Susan et al. 1997. Evaluating Health Projects: Lessons from the Literature, Discussion Paper No. 356, Washington, D.C.: World Bank.

Stout, Susan and Timothy Johnston. 1998. Lessons from Experience: A Review of the World Bank's Health, Nutrition, and Population Portfolio. Draft OES, OEDST. Washington, D.C.: World Bank.

World Bank. 1995. Bureaucrats in Business: The Economics and Politics of Government Ownership. World Bank Policy Research Report. New York: Oxford University Press. 1996. The World Bank Participation Sourcebook. Environmentally Sustainable Development (ESD). Washington, D.C.: World Bank. 1997. Republic of Uzbekistan: Water Supply, Sanitation and Health Project. Staff Appraisal Report No. 15968-UZ. Washington, D.C.: World Bank, April 17, 1997. 1998. Social Inclusion and Poverty Reduction: A Technical Consultation on Albania and Armenia, April 27, 1998. 
1996. Sustainable Transport: Priorities for Policy Reform. A Development in Practice Book. Washington, D.C.: World Bank.

1994. World Development Report 1994: Investing in Health. New York: Oxford University Press.

1997. World Development Report 1997: The State In A Changing World. New York: Oxford University Press. 
Title

WPS2019 The Effects on Developing Countries of the Kyoto Protocol and Carbon Dioxide Emissions Trading

WPS2020 Trade Liberalization, Fiscal Adjustment, and Exchange Rate Policy in India

WPS2021 Balance, Accountability, and Responsiveness: Lessons about Decentralization

WPS2022 The Implications of Foreign Aid Fungibility for Development Assistance

WPS2023 Capital Inflow Reversals, Banking Stability, and Prudential Regulation in Central and Eastern Europe

WPS2024 Re-Engineering Insurance Supervision

WPS2025 Dynamic Capital Mobility, Capital Market Risk, and Exchange Rate Misalignment: Evidence from Seven Asian Countries

WPS2026 Circuit Theory of Finance and the Role of Incentives in Financial Sector Reform

WPS2027 Child Labor: Cause, Consequence, and Cure, with Remarks on International Labor Standards

WPS2028 Access to Markets and the Benefits of Rural Roads

WPS2029 Small Manufacturing Plants, Pollution, and Poverty: New Evidence from Brazil and Mexico

WPS2030 The Political Economy of Financial Repression in Transition Economies

WPS2031 Addressing the Education Puzzle: The Distribution of Education and Economic Reform
Author

A. Denny Ellerman

Henry D. Jacoby

Annelene Decaux

Delfin S. Go

Pradeep Mitra

Anwar Shah

Shantayanan Devarajan

Vinaya Swaroop

Samuel Talley

Marcelo M. Giugale

Rossana Polastri

Lawrie Savage

Hong G. Min

Biagio Bossone

Kaushik Basu

Hanan G. Jacoby

Susmita Dasgupta

Robert E. B. Lucas

David Wheeler

Cevdet Denizer

Raj M. Desai

Nikolay Gueorguiev

Ramón López

Vinod Thomas

Yan Wang
December 1998

December 1998

Contact

for paper

December 1998

T. Tourougui 87431

December 1998

C. Bernardo 31148

A. Shah 37687

C. Bernardo 31148

December 1998

M. Geller 85155

December 1998

H. Arbi

34663

December 1998

K. Labrie 31001

December 1998

B. Bossone 33021

December 1998

M. Mason 30809

December 1998

M. Fernandez 33766

December 1998

Y. D'Souza 31449

December 1998

T. Hailu 44396

December 1998

T. Shiel 36317 


\section{Policy Research Working Paper Series}

\begin{tabular}{|c|c|c|c|c|}
\hline & Title & Author & Date & $\begin{array}{l}\text { Contact } \\
\text { for paper }\end{array}$ \\
\hline WPS2032 & $\begin{array}{l}\text { Institutional Investors and Securities } \\
\text { Markets: Which Comes First? }\end{array}$ & Dimitri Vittas & December 1998 & $\begin{array}{l}\text { A. Yaptenco } \\
38526\end{array}$ \\
\hline WPS2033 & $\begin{array}{l}\text { Diversification and Efficiency of } \\
\text { Investment by East Asian } \\
\text { Corporations }\end{array}$ & $\begin{array}{l}\text { Stijn Claessens } \\
\text { Simeon Djankov } \\
\text { Joseph P. H. Fan } \\
\text { Harry H. P. Lang }\end{array}$ & December 1998 & $\begin{array}{l}\text { R. Vo } \\
33722\end{array}$ \\
\hline WPS2034 & $\begin{array}{l}\text { Information, Accounting, and the } \\
\text { Regulation of Concessioned } \\
\text { Infrastructure Monopolies }\end{array}$ & $\begin{array}{l}\text { Phil Burns } \\
\text { Antonio Estache }\end{array}$ & December 1998 & $\begin{array}{l}\text { G. Chenet-Smith } \\
36370\end{array}$ \\
\hline WPS2035 & $\begin{array}{l}\text { Macroeconomic Uncertainty and } \\
\text { Private Investment in Developing } \\
\text { Countries: An Empirical Investigation }\end{array}$ & Luis Servén & December 1998 & $\begin{array}{l}\text { H. Vargas } \\
38546\end{array}$ \\
\hline WPS2036 & $\begin{array}{l}\text { Vehicles, Roads, and Road Use: } \\
\text { Alternative Empirical Specifications }\end{array}$ & $\begin{array}{l}\text { Gregory K. Ingram } \\
\text { Zhi Liu }\end{array}$ & December 1998 & $\begin{array}{l}\text { J. Ponchamni } \\
31022\end{array}$ \\
\hline WPS2037 & $\begin{array}{l}\text { Financial Regulation and } \\
\text { Performance: Cross-Country } \\
\text { Evidence }\end{array}$ & $\begin{array}{l}\text { James R. Barth } \\
\text { Gerard Caprio, Jr. } \\
\text { Ross Levine }\end{array}$ & January 1999 & $\begin{array}{l}\text { A. Yaptenco } \\
38526\end{array}$ \\
\hline WPS2038 & $\begin{array}{l}\text { Good Governance and Trade Policy: } \\
\text { Are They the Keys to Africa's Global } \\
\text { Integration and Growth? }\end{array}$ & $\begin{array}{l}\text { Francis } \mathrm{Ng} \\
\text { Alexander Yeats }\end{array}$ & January 1999 & $\begin{array}{l}\text { L. Tabada } \\
38896\end{array}$ \\
\hline
\end{tabular}

